\title{
POLICE RULEMAKING REVISITED: SOME NEW THOUGHTS ON AN OLD PROBLEM
}

\author{
Gregory Howard Williams*
}

[S]elective enforcement [of the criminal law] should be open and aboveboard. . . [e]nforcement policy should be made through the kind of rulemaking procedure that has been highly successful in federal administrative agencies. . . .

[I] unequivocally reject the suggestion that the police should engage in rulemaking that directly affects the scope of the substantive criminal law. I do not think that the structure of our law permits the police to exercise this kind of authority. Perhaps more importantly, I am convinced that it would not be wise to accord the police this power, even if it were permissible to do so. ${ }^{2}$

Criticism is properly directed at the police for their failure to develop policies to control arrest decisions. Scholars, however, have not provided the police with examples of appropriate ways to structure such decisions. In addition to having failed to provide necessary guidance, scholars continue to disagree on the scope and extent of constitutional and statutory power to develop discretion-limiting rules and guidelines.

The debate between Professors Kenneth Culp Davis and Ronald Allen exemplifies the extent of the disagreement among scholars. Professor Davis, in his book entitled Police Discretion, asserts that local police departments have the legal authority to draft law enforcement rules. ${ }^{3}$ Davis maintains that the police may develop such rules because there is an implicit delegation of the power to do so by the state legislatures. ${ }^{4}$ According to Davis's theory, state legislators have acquiesced in law enforcement policymaking by failing to provide adequate funds for law enforcement agencies, and by neglecting to amend or repeal laws which legislators know cannot be enforced fully. ${ }^{5}$ In addition, Davis contends that the constitutional principle of due process,

Copyright (C) 1984 by Law and Contemporary Problems

* Professor, College of Law, University of Iowa, former law enforcement officer, and currently Chairperson of the Iowa Law Enforcement Academy Council.

I am appreciative of the comments on earlier drafts received from Ronald J. Allen, Northwestern University; Richard Kuhns, Washington University; Peter Shane, University of Iowa; Herman Goldstein and Frank Remington, University of Wisconsin; Albert Reiss of Yale University; and John A. Morgan, Jr., Robert Park, and Erick Sirulnik of George Washington University. I would also like to thank Kim Dulin, Matthew Petrzelka, and Brian Regan of the University of Iowa College of Law for their research assistance. This article is based in part on research that appeared in chapters 1 and 2 of The Law and Politics of Police Discretion, published in 1984 by Greenwood Press, Westport, Conn.

1. K. Davis, Police Discretion 168 (1975).

2. Allen, The Police and Substantive Rulemaking: Reconciling Principle and Expediency, 125 U. PA. L. REv. 62, 67 (1976).

3. K. Davis, supra note 1 , at 90 .

4. Id. at 107-12.

5. Id. at 80-81. 
which mandates development of enforcement policy by administrative agencies, mandates similar policy development by law enforcement agencies. ${ }^{6}$

Although there was general acceptance of Davis's argument when it was first articulated, Professor Allen later raised some serious questions regarding the constitutional basis for Davis's conclusion. ${ }^{7}$ After looking closely at Davis's work, Allen concluded that law enforcement policymaking is impermissibly inconsistent with our theory of government, in that it amends or repeals the criminal law, a task reserved for the legislature. ${ }^{8}$ To a substantial extent, the positions held by Allen and Davis represent a clash between theory and reality.

Professor Davis appears to be strongly influenced by the unlimited discretion the police exercise and the lack of governmental control over them. In his desire to address a serious problem, he attempts to apply to police work the constitutional theory and body of law that have supported the development of enforcement policy by federal administrative agencies. Since Professor Davis does not amplify his points or give sufficient consideration to some of the unique aspects of state and local law enforcement agencies, his theory is limited in several respects. For example, while Professor Davis discusses fourteenth amendment due process theory, he does not fully develop the separation of powers and delegation problems at the state level, nor does he analyze the unique problems that arise from considering the police as an administrative agency.

Professor Allen, on the other hand, minimizes the practical problems of law enforcement. His approach is straightforward, but it tends to be excessively principled and theoretical. Allen contends that the principles of separation of powers and delegation simply do not permit the type of rulemaking contemplated by Davis and that Davis's administrative agency analogy is inappropriate. Largely because of the different perspectives of the two writers, there is sharp disagreement on some points while others are addressed inadequately or not at all.

Owing to the significance of the issue whether police can formulate enforcement rules, there is an urgent need to consider carefully the unanswered questions and the areas of disagreement. The purpose of this article is to analyze the strengths and weaknesses of the positions taken by Davis and Allen, and to attempt to develop a more complete understanding of the constitutional and statutory basis for police rulemaking. Since "full enforcement" statutes 9 have been central to most of the discussions surrounding

6. Id. at 131-38.

7. Allen, supra note 2, at 75-76.

8. Id. at 80. While Professor Allen looks at law enforcement policymaking by the police in the context of a more rigorous constitutional analysis, he does not assess the historical role of the police as an institution of government. For example, his classic separation of powers analysis is limited by an assumption that a police department is an executive agency exercising only the power of the executive branch. Furthermore, he does not address the due process or equal protection problems.

9. See infra note 50. 
police rulemaking, it is important to analyze not only the language of the statutes but also the context within which they were developed. Consequently, the article will begin with an analysis of the history and language of those statutes. ${ }^{10}$ A discussion of constitutional principles of separation of powers and delegation, and their impact on police rulemaking, will follow. Finally, the article will review constitutional principles of due process and equal protection, with a focus on the significance those principles have for developing law enforcement policy.

\section{I}

\section{Historical Development of Police Discretion}

Conspicuously absent in the debate between Allen and Davis is an understanding of the historical evolution of police discretion. Professor Davis, while discussing police discretion in a more theoretical framework in his book, Discretionary Justice, ${ }^{11}$ seems to base his specific recommendation for law enforcement rules on his observation and evaluation of the Chicago Police Department. ${ }^{12}$ Thus, he recommends specific changes, apparently because of what he saw as the basic unfairness of uncontrolled discretion exercised by members of only one contemporary law enforcement agency. On the other hand, Professor Allen talks about the need "conceptually . . . [to] locate the police in relation to other principal decisionmakers in the criminal law process."'13 But, like Professor Davis, he fails to consider the historical development of the police and the effect this history has on their present role.

The end result is that both Davis and Allen, drawing from their limited analyses, make some unwarranted assumptions and reach questionable conclusions. Professor Davis, for example, argues that the police are similar to federal administrative agencies with similar power to establish law enforcement policy. Professor Allen conceives of administrative agencies as bodies created to regulate how society functions in certain areas; he sees the police, on the other hand, as called upon only to enforce laws enacted by the legislature. According to Professor Allen, "[W]e do not say to the police: 'Here is the problem. Deal with it,' " as Professor Davis contends. ${ }^{14}$ Rather, Professor Allen would say: "Here is a detailed code. Enforce it."15 Thus, Professor

10. See infra notes 47-95 and accompanying text. For a detailed analysis of how to develop rules that control police discretion, see Williams, Police Discretion: The Institutional Dilemma-Who Is In Charge?, 68 Iowa L. Rev. 431 (1983).

11. K. Davis, Discretionary Justice: A Preliminary Inquiry (1969).

12. Davis conducted an extensive number of interviews with members of the Chicago Police Department and apparently was concerned with the lack of control maintained over the discretionary action of patrol officers. K. Davis, supra note 1 , at 167-71.

13. Allen, supra note 2, at 70 (quoting Goldstein, Police Discretion Not To Invoke the Criminal Process: Low-Visibility Decisions in the Administration of Criminal Justice, 69 YALE L.J. 543, 554 (1960)). Professor Davis asserted that police departments operated as administrative agencies and they should be viewed as such. Allen, aided by Davis's limited development of the administrative agency analogy, easily rejected it and proceeded to develop powerful arguments against discretionary enforcement policymaking.

14. Id. at 97 (quoting $\mathrm{K}$. Davis, supra note 11 , at 4-5).

15. Allen, supra note 2, at 97. Professor Allen refers to the different roles of the police and 
Allen sees a different mandate given to the police than to administrative agencies.

Because of Professor Davis's limited development of the administrative agency analogy, especially with regard to the application of the doctrine of separation of powers to the police, Professor Allen's arguments acquire more weight than might appropriately be due them. The failure of Professor Davis to expand on the theory of the police as a state administrative agency enables Professor Allen, in rebuttal, to engage in a discussion of the separation of powers doctrine without articulating how the police fit into that doctrine.

An analysis of the historical development of the police clearly shows the police as an agency with a long tradition of performing discretionary functions, and, in fact, of supervising peace-keeping relationships. Not only is history replete with examples of the police acting as an independent agency ${ }^{16}$ exercising broad law enforcement powers, but there are also examples of the police exercising legislative ${ }^{17}$ and judicial ${ }^{18}$ functions.

The police as we know them in modern America trace their origin to early England. The first significant law enforcement officer, the English sheriff, exemplifies the manner in which the police function was not limited strictly to that of an agency exercising only ministerial functions. The English sheriff was an extremely important person in his community. He functioned much like a viceroy: "He received and interpreted the king's mandate not only in matters concerning civil order, but in military, fiscal and judicial affairs as well."19

In addition to being the most significant law enforcement officer, the sheriff was also judicial president of the shire and responsible for administration of the royal demesne. ${ }^{20}$ Thus, the sheriff had the authority to exercise both judicial and executive powers. Largely because of his administrative duties as royal tax collector, the sheriff was generally an unpopular person. ${ }^{21}$ This basic unpopularity, combined with frequent occurrences of corrupt acts by sheriffs in the collection of taxes, ultimately led to efforts to control the English sheriff. ${ }^{22}$

administrative agencies. Administrative agencies, he contends, are "regulatory bodies created to supervise relationships within their jurisdictions," while the the police "are to enforce prohibitions articulated by the legislature." The police, then, according to Professor Allen, "perform a very different function from that of a regulatory agency." Id.

16. See, e.g., IND. Const. art. VI, $\$ \S 2-11$, listing sheriffs in the section pertaining to administrative agencies.

17. See infra note 35 .

18. See B. Smith, Police Systems in the United States 80-81 (1940) ("It is important to emphasize that the institutional segregation of the police from the judiciary is a relatively recent phenomenon and that it is particularly characteristic of the English and American models of law enforcement. Under the common law, the Justice of the Peace was the magistrate and the chief police officer in his jurisdiction."); see also E. BitTner, The Functions of the Police in Modern Society: A Review of Background factors, Current Practices and Possible Role Models 31 (1975).

19. B. SMITH, supra note 18 , at 80 .

20. Id.

21. Id.

22. B. Smith, Rural Crime Control 39 (1933); see also J. Hall, The History and Philosophy 
It is clear, however, that efforts to control the sheriffs did not rest upon the feeling that the extensive power of the sheriff violated any particular theory or principle of government; rather, the concern was with the corruption of the officeholders. ${ }^{23}$ In fact, during the time that attempts to control corruption of the sheriffs were undertaken, many of the sheriffs were able to secure appointments as justices of the peace, thus continuing to exercise both executive and judicial functions. ${ }^{24}$

Like the sheriff, the constable was another law enforcement officer who had broad discretion. In the Middle Ages, the English constable served not only as a law enforcement officer but as a magistrate as well; he interpreted statutes, enforced them, and penalized violators. ${ }^{25}$ While the rise of the justice of the peace ultimately resulted in the decline of the magisterial powers of the constable and the sheriff, there continued for many years to be a much closer working relationship between those officials and the justice of peace than between the sheriff and constable and the executive arm of the government. ${ }^{26}$

The justices had extensive discretion in enforcing the laws, and, to assist them in the exercise of that discretion, they had the constable and the sheriff. ${ }^{27}$ Both served for many years as adjuncts to the justices of the peace. By the sixteenth century, the justices were firmly entrenched and the broad powers of the constable and the sheriff had eroded. Nonetheless, the constables and the sheriffs continued to perform a wide range of duties. ${ }^{28}$ Even in the late 1800's, the sheriffs and the constables retained considerable discretionary powers. ${ }^{29}$ However, law enforcement duties in England by that time had been largely taken over by Peel's "New Police."30

As in England, the primary law enforcement officer in colonial America

OF LAW ENFORCEMENT (1975). "Originally a very powerful man on the local law enforcement scene, by the end of the 1200 s the Crown had cause to resent and suspect some of the abuses of power that were being perpetrated by the local sheriff. During the following century steps were taken to curtail his power somewhat." Id. at 47 .

23. Id. at 41 .

24. W. Lee, A History of Police in England 46 (1901).

25. В. SмIтн supra note 18 , at $82-83$.

26. In fact, one writer observed, "It is impossible . . . to divorce the functions of the justice from the constable." W. LEE, supra note 24 , at 43.

27. Id. at 54 .

28. C. Karraker, The Seventeenth Century Sheriff 21 (1930) ("In still other matters of county administration the sheriff frequently acted as an associate of the justices of the peace."). The Privy Council was also dependent on the sheriff and the justices for the capture of criminals and for the suppression and investigation of disorders in various parts of the county. Id. A justice of the peace who had a cause before his court, would, "in a venire facias directed to any constable of the city or town where the cause [was] to be tried, command him to summon a jury for the trial." The constable essentially brought the justice a panel of such names summoned by the venire and the justice drew such names until he got a jury of six. $2 \mathrm{~J}$. Backus, A Digest of Laws Relating to the Offices and Duties of Sheriff, Coroner and Constable 82 (1812).

29. F. Maitland, The Constitutional History of England 39, 233-34, $485-90$ (1931).

30. Sir Robert Peel, Home Secretary in the Duke of Wellington's administration, issued the order creating the "New System of Police" in September 1829, in London. Most law enforcement scholars trace the origin of the modern police force to this event. D. Bayley, Police And Society 73 (1977); see also F. MAITLAND, supra note 29 at 487. 
was the sheriff. The American sheriff, like his English counterpart, possessed extensive power and authority. Like their English counterparts, the earliest sheriffs in America were agents of the King and appointed by the Governor of the colony.

For the most part the colonial sheriffs were closely modeled upon their English contemporary. The power of appointment was usually vested in the governor, and the sheriff's duties so distributed as to include not only the apprehension of offenders, the care of prisoners, and the execution of civil process, but also the conduct of elections, collection of taxes, custody of public funds, and other fiscal operations. In some cases the judicial function adhered to the office for a time, particularly in Virginia . . . .31

Also as in England, it was largely the non-law-enforcement duties performed by sheriffs that led to concern about the sheriffs' powers. According to one scholar, "[T]his practice of frequent rotation in the office of sheriff was not so much based upon democratic doctrines, as upon the fact that the colonial sheriff . . . was often charged with the collection of taxes and proved dilatory in settling his accounts for them." 32 The Americans dealt with the sheriff problem in quite a different way than did the English. In England, the attempts to control the corruption of the sheriffs resulted in limiting the broad powers of the office. ${ }^{33}$ The American approach to limiting corruption, however, was not to restrict the powers, but to ensure public accountability of the officeholder. In essence, it was felt that the sheriff could be controlled by making his position elective. ${ }^{34}$ Thus, the trend in America was to increase public control by requiring election and limiting the sheriff's tenure in office, rather than by establishing rigid boundaries within which the sheriffs were expected to function.

Attempts to categorize the sheriff's office and powers as being solely executive, legislative, or judicial are complicated by several factors. First, while the American sheriff functioned on the local level, he was in most states an elected public official and his office was specifically created in the state constitutions. State constitutions gave sheriffs power over a discrete area but required fealty and allegiance to the state at large. In each county, the sheriff had exclusive power to determine law enforcement priorities, and any controls on the sheriff's power were indirect. No state or local official had the power specifically to direct the sheriff in the performance of his day-to-day duties. ${ }^{35}$ The inability of agencies to control the daily operation of other constitutional officers is well noted, and there appear to be no compelling reasons, other than devotion to the myth of full enforcement, to think that the sheriffs are any different.

31. B. SмIтH, supra note 22 , at $42-43$.

32. Id. at 45 .

33. B. SмIтн, supra note 18 , at $81-82$.

34. Id. at 84-86.

35. In some states the governor had the power to remove the sheriff from office. Id. at 85 . The political independence of bodies established by state constitutions has been made clear in other state court decisions. Article VIII, section 5 of the Michigan Constitution, for example, provides for the boards of regents of the respective state universities to be directly elected by the people for eightyear terms and for the boards to constitute independent corporate bodies. Moreover, absent from section 5 (which provides that each board of regents "shall have general supervision of its institution 
County governing bodies normally provided the sheriff's budgetary needs, and state legislatures passed the laws to be enforced. Even if local government officials took the position that particular state laws were to be enforced fully in their locality, they could not order the sheriff to comply with their wishes. Of course, one could argue that the power of the purse held by county officials might force a reluctant sheriff to adhere to the enforcement wishes of the county officials. That argument, however, reinforces the idea that sheriffs were policymakers operating within a particular sphere of influence, and that the enforcement of criminal statutes, like that of other statutes, frequently was the subject of negotiation among political agencies.

Historical examination of two agencies which conceivably could compel full enforcement of the law reveals that they rarely did so. While legislatures passed criminal statutes, rarely did they review how those statutes were enforced. The sheriffs were left to decide on specific implementation of the laws. Furthermore, there are very few cases in which the courts required full enforcement of the law. One plausible conclusion is that the drafters of the state constitutions that established the office of sheriff intended that sheriffs be politically independent and publicly accountable officials whose selection and performance would not be controlled directly by any state or local official. ${ }^{36}$ That is not to say that they were to be considered completely autonomous, but that sheriffs, like most other states and local officials, were expected to exercise broad powers within a framework of practical politics and statutory law. In spite of state constitutional revisions that have occurred across the nation, the position of the sheriff as an independent, elected state official basically has not changed. ${ }^{37}$

and the control and direction of all expenditures from the institution's funds") is the more typical qualifier-"as may be prescribed by law." The Michigan courts were quick to acknowledge that, under the state constitution, "the board of regents is made the highest form of juristic person known to the law, a constitutional corporation of independent authority." Board of Regents v. Auditor General, 167 Mich. 444, 450, 132 N.W. 1037, 1040 (1911). Hence, once the legislature appropriates money to the University, it passes to the regents and becomes the property of the University, to be expended under the exclusive direction of the regents, and passes beyond the control of the state through its legislative department. Legislative approval of University expenditures is not required since the University and its regents were not created by the legislature. See Bauer v. State Bd. of Agriculture, 164 Mich. 415, 129 N.W. 713 (1911) (state board of agriculture has the exclusive control to appropriate funds for general purpose of agriculture college just as the board of regents has been held to possess similar power). Similarly, a statute which required that a performance bond be secured from a principal contractor before a "public educational institution," inter alia, could award a contract exceeding $\$ 5,000$ for the repair of any public building (or other public work), was held to apply only to those colleges and universities whose governing boards were not created in the constitution. Reichenbach v. Michigan, 94 Mich. App. 323, 288 N.W.2d 622 (1979). For matters within the scope of the regents' functions, other state officers, like the auditor general, perform purely ministerial duties as compared to the regents. Board of Regents, 167 Mich. at 452, 132 N.W. at 1041 .

36. In Rhode Island, the legislature selected the sheriffs, and one might argue that this made sheriffs legislative officials. Selection of sheriffs by state legislatures, however, clearly was not a common practice nationally. J. Dealey, Growth of American State Constitutions 248 (1915). The Mississippi Constitution speaks of the sheriff as a county officer, although he has constitutional status. Miss. Const. $\S \S 135,138$.

37. For example, the state of Maryland attempted to eliminate the office of sheriff from its constitution in a draft revision, but the attempt failed. See Constitutional Convention Commission, Report of the Constitutional Convention Commission 366 (1967). 
If sheriffs cannot be classified as legislative, executive, or judicial officials according to which branch of government has direct control over their decisions in office, can they be so classified by the specific functions they have been given to perform? As a general proposition, the functions of the sheriffs have not changed substantially since the American Revolution. Looking at the specific powers of the sheriffs, one gets a better idea of the role they are expected to play in government, and a picture of the office as an independent government agency begins to emerge. The sheriff had duties as court administrator, jailer, peace officer, tax collector, and election supervisor. ${ }^{38}$ None of those duties-not even that of peace officer-can in any practical sense be regarded as having no policymaking components. ${ }^{39}$ All of these tasks required the sheriff to analyze facts within the context of relevant statutes and to make policy judgments regarding enforcement of those statutes.

The argument that the sheriff is to exercise broad policymaking discretion is reinforced by the constitutional status of the office. It is clear that the framers of the early state constitutions felt that sheriffs, like officials in other agencies of government, warranted an exception to the rigid application of the separation of powers theory. This was certainly true in other cases in which

the principle of separation of powers was violated in practice by legislative exercise of judicial and executive functions; by the election of the executive councils by and from the legislatures; by the appointment of judicial and executive officers by the legislature; by the presidency and vote of the vice-executive in the upper house; and by the exercise of judicial functions by the governor and his council. ${ }^{40}$

One can conclude from this curious state of affairs that any interpretation of state separation of powers provisions which fails to consider the constitutional status of the first law enforcement officer in America, the sheriff, is seriously deficient. Unfortunately, Professors Allen and Davis overlooked the implications of the historical evolution of law enforcement in America by focusing exclusively on today's most prominent law enforcement agency-the municipal police. ${ }^{41}$ While the origin of the municipal police may be somewhat different from that of the sheriff, the two do share a common institutional responsibility; thus, their power and authority may well be based on similar theories regarding the allocation of power.

Because municipal police officers rarely are mentioned in state constitutions, a scholar focusing only on them does not encounter the problem of trying to counterbalance separation of powers provisions of state constitutions with those which establish sheriffs as independent agencies. While the

38. W. Jackson, The Office of Sheriff in lowa 14-43 (1924) (unpublished Ph.D. dissertation, Department of Political Science, University of Iowa).

39. In fact, sheriffs have been called the "central administrative post in a community." $B$. SMrTh, supra note 22, at 46-54.

40. F. Green, Constitutional Development in the South Atlantic States, 1776-1860, at 8384 (1930).

41. Allen, supra note 2, at 62-70; Davis, supra note 1 , at iii. 
existence of state constitutional provisions establishing the independent character of the office of sheriff does not alone fully clarify the intended scope of sheriff's powers, it certainly helps in that regard.

As we have seen, the early sheriffs were assigned a variety of administrative tasks and responsibilities both before and after ratification of the state constitutions. In fact, sheriffs could be considered as one of the first independent administrative agencies. ${ }^{42}$ After examining the historical role of the sheriff, the administrative agency analogy drawn by Professor Davis becomes much more plausible. The analogy is less clear, though not untenable, when the focus is on municipal police departments. Even if there is some inconsistency between the establishment of the sheriff and the municipal police as institutions of government, the basic approaches to distributing law enforcement powers seem quite similar.

Politics has had a major impact on law enforcement, although it has been dealt with in different ways at the county and municipal levels. The openly political nature of the sheriff's office over the years has remained largely unchanged, but the political nature of the police has evolved in another way. ${ }^{43}$

42. See supra note 39 .

43. The fights for control among the police in New York City typify the struggles that have occurred nationally. R. Fosdick, American Police Systems 58-117 (1920 \& reprint 1969). Around 1857, there were efforts in New York to introduce Sir Robert Peel's concept of modern law enforcement, although such efforts had strong political overtones. At that time legislation was introduced in the state legislature which consolidated the boroughs of New York City and created a Board of Police Commissioners consisting of the mayors of New York and Brooklyn and five commissioners appointed by the Governor. Id at 78-80. This new legislation marked the introduction of direct state control over local law enforcement, and "represented the maneuvering of a Republican legislature to obtain control over the affairs and particularly the patronage of a Democratic city." Id. at 84 . That the move was political is demonstrated by the fact that the Governor appointed four Republicans and one American Party man to the Board. Id. at 85. Needless to say, this "reform" effort created great controversy, but there was little change until a Democratic governor was elected. Shortly after the election of a Democratic governor, the Republican-controlled state legislature passed a statute which gave the state legislature the power to appoint the members of the Police Board. It is unclear whether this action was the result of a desire by the Republican-controlled legislature to limit the power of a Democratic governor or was aimed at bringing about bipartisan membership of the Police Board. Partisan politics probably played some role in this case, but the establishment of bipartisan agencies to oversee the police was an idea generally becoming increasingly popular. Id. at 89 .

By the early twentieth century in New York at least ten different state or local officers or commissioners had been used to supervise local police activities. Id. at 109-10. This ever-changing search for ways to exert political control over the police led one police scholar to lament:

In this blind search for the "ideal system," this belief in the efficiency of checks and balances, if only the proper combination can be discovered, continuity has been sacrificed, and the existing arrangements have again and again been overturned. In the 91 years in which the Metropolitan police organization of London has been in existence, but one substantial change has been made in its machinery of control, and that was in 1856, when, after six years of trial with a singleheaded commission the act of 1829 providing for two commissioners was altered to fit the new condition. In the 75 years in which New York City may legitimately be said to have had a regular police force nine fundamental changes, involving distinct breaks with the past, have occurred in the framework of her organization.

Id. at 111 .

Attempts at state control of local law enforcement were obviously unpopular in the large cities. In fact, it is plausible that the real push for home rule was motivated in large part by a desire to avoid state control of local police. Whether the concern about control of the police motivated or succeeded the movement for home rule, there was a decline in direct state involvement in local law 
Early American police departments were first and foremost partisan political institutions: officers were selected on the basis of their political affiliation and such selection strongly influenced how they performed their duties. ${ }^{44}$ Because of the vast powers of social control inherent in police work, there were constant struggles to see which political group would control the police. ${ }^{45}$

In spite of all the fighting between state and local governments over control of the police, the police continued to exercise a wide range of duties, including the interpretation of the laws to be enforced. ${ }^{46}$ The battles for political control had nearly ended by the turn of the century and general responsibility for supervision of local police was placed at the municipal level. Thus, the police departments had begun their development into independent bureaucracies. State interest, to the extent it can be classified as interest in how laws were enforced, took on a slightly different flavor in the form of statutes establishing police agencies as integral and semi-independent branches of local government.47 Many of those statutes included the general and largely nondirective provisions which have been referred to as "full enforcement" clauses.

enforcement, and by the turn of the century new means had been adopted to control the police. Fluctuations in control of the police, and particularly intervention of state government in local law enforcement, were not unique to New York. In 1860, the Maryland state legislature created a police board for the city of Baltimore consisting of four commissioners selected by the state legislature; the following year the legislatures of Missouri and Illinois created police boards for the cities of St. Louis and Chicago, respectively, stipulating that board members be selected by the Governor and approved by the state senate. State-controlled boards were also introduced in Michigan, Ohio, Louisiana, Nebraska, California, and Massachusetts. State boards seem to have been instituted primarily because state officials wanted to limit Democratic influence in local law enforcement policy decisions, which frequently were in direct conflict with the policy objectives of Republican-controlled state legislatures. Id. at 90-96. Later, to avoid politicization of state police departments, some provisions were made in the states to ensure equal representation in those departments. See, e.g., Iowa Code $\S 1225.09$ (1939):

The Commissioner shall succeed in the administration and control of the Iowa Highway safety patrol established under chapter 134, acts of the forty-seventh general assembly. The Commissioner is authorized to employ the members of said patrol; however, not to exceed one hundred twenty-five men, and not more than sixty percent of said patrol shall at any time be members of the same political party. Provided, however, the present personnel of the highway patrol in good standing are excepted from the provisions of this section.

44. B. Smith, supra note 18 , at 4 ; see also A. Levett, Centralization of City Police in the Nineteenth Century United States (1975) (unpublished Ph.D. dissertation, University of Michigan).

45. It is significant that while there were numerous battles for control of the police, rarely was there any effort to limit police powers. R. Fosdick, supra note 43, at 211-13.

46. Id. at 213; see also F. Goodnow, Municipal Government 258-316 (1925). Goodnow specifies the phrase "administrative police." While one of the main functions of administrative police is the preservation of the peace and the maintenance of order, the phrase according to Goodnow has much wider meaning.

47. However, the theory that the police are state officers has not been modified. The language of Buttrick v. City of Lowell, 83 Mass. (1 Allen) 172, 173 (1861), continued to convey the idea that the state had ultimate control of the police: "Police officers can in no sense be regarded as agents or servants of the city. Their duties are of a public nature. Their appointment is devolved on cities and towns by the legislature as a convenient mode of exercising a function of government." Buttrick has not been overruled. See also Culver v. City of Streator, 130 Ill. 238, 22 N.E. 810 (1889); Prather v. City of Lexington, $52 \mathrm{Ky}$. (13 B. Mon.) 559 (1852). 


\section{Full Enforcement Statutes}

Professor Allen argues that the so-called "full enforcement" statutes "consistently purport to deny police the discretion not to invoke the criminal law." 48 He stresses, however, that "the policies that shape these statutes must also be examined for insights into the proper role of the police." 49 Upon close examination, the situation is much more ambiguous than Professor Allen would lead us to believe. An analysis of the full enforcement provisions, in the total context of the statutes in which they are included, indicates that they are a minor part of legislation primarily designed to create independent police departments acting within general guidelines. ${ }^{50}$ The extreme and narrow focus on the so-called full enforcement provisions may simply illustrate the ability of scholars to focus on language rather than on underlying principles.

Despite the relatively minor role of the full enforcement provisions, they warrant a closer look due to the questions which have been raised regarding their effect on police rulemaking. A significant number of the full enforcement statutes were enacted around the turn of the century; fourteen of the twenty-three states that Professor Allen cites as having full enforcement statutes enacted them between 1883 and $1925 .{ }^{51}$

48. Allen, supra note 2 , at 71 .

49. Id. at 75. Actually usage of the term "full enforcement" to describe the statutes may itself be a misnomer, as the "full enforcement" provisions are in actuality a very minor part of these statutes. In fact, at least one court has referred to such legislation as the "peace statute" which may be a more accurate reflection of the objective of the statute. See City of Emmetsburg v. Gunn, 249 Iowa 297 , 303, 86 N.W.2d 829, 834 (1957). Scholars have been of little help in interpreting the full enforcement statutes. There has been a failure to develop an understanding of the historical background of the statutes, and the language of the statutes has been subjected to only cursory examination. The general approach has been to remark on the similarity of the statutes and to analyze only selected segments before drawing conclusions about their purpose and application. See e.g., Allen, supra note 2, at 71; W. LaFave, Arrest 76-79 (1965).

Also there has been some confusion over the exact number of such statutes. Professor Joseph Goldstein, the first person who attempted to list the full enforcement statutes, found 20 statutes in 1960. Goldstein, Police Discretion Not to Invoke the Criminal Process: Low-Visibility Decisions in the Administration of Justice, 69 YALE L.J. 543, 557 n.26 (1960).

Professor Wayne LaFave, in his 1965 work, found twelve "pure" full enforcement statutes (applying to all state law enforcement officers), eight statutes that specifically mandated full enforcement by state sheriffs, seven statutes that required full enforcement by local police, three statutes that required peace officers to arrest "all felons," and four statutes that required the arrest of all persons committing an offense in an officer's presence. LaFave, supra, at 76-77.

Professor Allen found 23 states to have statutes "mandating either that the law enforcement agencies arrest all who violate the criminal law or that the agencies enforce all the criminal laws." Allen, supra note 2 , at $71 \mathrm{n} .48$. Allen also found two other statutes requiring peace officers to arrest all persons committing offenses in their presence and two statutes directing the police to arrest all felons. Id.

The figures used by Allen and Goldstein are misleading because they include, as pure full enforcement statutes, statutes which are specifically directed either to local police or to sheriffs. Approximately 34 states within the past 20 years have had some type of "full enforcement" legislation.

50. See infra notes $70-96$ and accompanying text.

51. See, e.g., Act of March 14, 1883, ch. 75, § 92, 1883 Cal. Stat. 299, 320; Act of Mar. 11, 1891, ch. 55, § 3, 1891 N.D. Sess. Laws 141 ; Act of Feb. 25, 1891, ch. 45, § 1, 1891 Wash. Laws 83-84; Act 
The question that must be answered is why such a large proportion of the statutes were enacted between 1883 and 1925. As indicated earlier, ${ }^{52}$ during that time there was throughout the country considerable tension between state and local governments over who was to control municipal police. ${ }^{53}$ Thus, one plausible explanation might be that the full enforcement provisions were an attempt to maintain some vestige of state control over local police. A more plausible hypothesis, however, is that the legislation was a genuine attempt to foster the creation of politically independent, yet locally selected, police departments. The latter theory, that the various state legislatures were motivated to enact such legislation by their interest in developing more politically insulated municipal police agencies, draws considerable support from a close analysis of the enabling statutes of which the full enforcement provisions were part.

The language and general context of the enabling statutes supports the proposition that the state legislatures were intent primarily upon establishing

of May 27, 1895, ch. 12, § 4, 1895 Mich. Pub. Acts 429; Act of Mar. 16, 1901, ch. 18, § 30, 1901 Neb. Laws 238; Act of March 6, 1905, ch. 129, $\S 161,1905$ Ind. Acts 339-40; Act of Mar. 10, 1908 , ch. 157, $\S 61,1908 \mathrm{Va}$. Acts 209; Act of June 3, 1920, ch. 591, § 24, 1920 Mass. Acts 632; Act of Mar. 12, 1921, ch. 170, $\S 1,1921$ N.M. Laws 362 . The present full enforcement statutes include the following: Ala. Stat. $\$ 18.65 .080$ (1981); Ariz. Rev. Stat. Ann. \& 11.441 (Supp. 1983); Ark. Stat. AnN. $\$ 17-3601(5)$ (1980); Cal. Gov't Code $\$ 26601$ (West 1968 \& Supp. 1984); Colo. Rev. STat. $\S 30-10-516$ (1973); Del. Code Ann. tit. 11, § 8302 (1974); Fla. Stat. Ann $\S 30.15$ (West 1976); Hawail Rev. Stat. § 6-52-67 (1976); Idaho Code § 19-4804 (1979); Ind. Code § 36-2-13-5 (Supp. 1983); ME. Rev. Stat. AnN. tit. 15, § 704 (1964); Mass. AnN. Laws, ch. 41, § 98 (Law Co-op. 1983); Mich. Stat. Ann. \& 5-1752 (Callaghan 1949); Neb. Rev. Stat. § 16-323 (1977); N.M. Stat. Ann. § 4-41-2 (1978); N.D. Cent. Code § 11-15-03 (Supp. 1983); Ohio Rev. Code ANN. § 737.11 (Page Supp. 1983); Utah Code ANn. \& 10-6-66 (1953), § 17-22-2 (Supp. 1983); VA. Code § 15-1-138 (Supp. 1981); Wash. Rev. Code ANN. § 36.28.010 (Supp. 1984); W. VA. Code § 8-14-3 (1984). Statutes requiring officers to arrest all persons committing crimes in their presence include: ILL. AnN. Stat. ch. 125, § 82 (Smith-Hurd Supp. 1984); Ind. Code Ann. § 36-2-13-5 (Supp. 1984). Statutes requiring officers to arrest all felons include: MinN. STAt. ANN. $\$ 387.03$ (West 1968); Mo. AnN. Stat. \& 57.100 (Vernon Supp. 1984).

52. See supra note 43 and accompanying text.

53. State-controlled police systems had been implemented in 12 of the 23 American cities that had populations larger than 250,000 in 1915 . Those 12 cities were located in 10 states. R. Fosdick, supra note 43 , at 97 , lists the cities whose population exceeded 250,000 according to the census estimates of 1925: Baltimore, Boston, Chicago, Cincinnati, Cleveland, Detroit, Indianapolis, Kansas City, New Orleans, New York, San Francisco, and St. Louis. Eight of the cities had some type of full enforcement legislation at that time, and six enacted such legislation within nine years of the return of police control to municipal governments. In fact, five of these $\mathbf{1 0}$ states enacted full enforcement legislation within four years of the return of police supervisory control from the states to the cities.

$\begin{array}{lll} & \text { End of State } & \begin{array}{l}\text { Enactment of } \\ \text { Full Enforcement } \\ \text { Legislation }\end{array} \\ \text { Catate } & \text { Control of Police } & 1883 \\ \text { Indiana } & 1900 & 1905 \\ \text { Illinois } & 1891-1901 & 1874 \\ \text { Louisiana } & 1865 & 1928 \\ \text { Maine } & 1877 & 1920 \\ \text { Maryland } & 1920 & \text { NA } \\ \text { Michigan } & \text { NA } & 1895 \\ \text { Missouri } & 1981 & 1949 \\ \text { New York } & \text { NA } & 1888 \\ \text { Ohio } & 1870 & 1902\end{array}$

Figures compiled by author from R. FosDICK, supra note 43 . 
general rather than specific operational control of local police. The major concern of the legislatures, so expressed in the statutes, was with the design and structure of local police agencies, and not with controlling police decisionmaking. Many of the full enforcement statutes were placed in the "political," as opposed to "criminal," sections of the state codes. The New York Legislature, for example, frequently incorporated full enforcement language into municipal charters. ${ }^{54}$ Full enforcement legislation in California, Indiana, Michigan, Nebraska, Ohio, and sixteen other states was part of legislation primarily enacted to establish city and county governments. ${ }^{55}$

Only six state legislatures enacted full enforcement legislation as part of the state criminal code. ${ }^{56}$ In such cases, there is greater reason to view the full enforcement statutes as explicit commands. Judging from the placement of the full enforcement statutes, however, it appears that the various state legislatures were more concerned with outlining general duties and responsibilities of municipal government than with specifying requirements concerning law enforcement.

Whether full enforcement statutes are placed in criminal or political sections of state codes, however, is not dispositive; a more important question is how the statutes have been interpreted by the courts. Unfortunately, there is little case law interpreting the legislation. In Iowa, for example, City of Emmetsburg v. Gunn ${ }^{57}$ is the only reported case interpreting the full enforcement

54. While the language was not always the same, it generally followed the format of the town of Flatbush.

Subsection 13. It is hereby made the duty of said police force at all time of the day or night, within the said district, and the members of said force are accordingly thereunto empowered, especially to preserve the public peace, prevent crimes, detect and arrest offenders, suppress riots and insurrections, protect the rights of persons and property, guard the public health, preserve order at every primary and public election, report nuisances in streets and roadways, restrain disorderly houses and houses of ill-fame, observe and inspect all places having excise or other licenses to carry on business, arrest beggars, protect property at fires, assist travelers, and enforce all laws relating to the suppression and punishment of crimes and disorder and all violation of the excise law.

Act of June 9, 1888, ch. 556, $\S 13,1888$ N.Y. Laws 912, 915 (emphasis added).

55. Alaska Stat. \$18.65.080 (1981); Ariz. Rev. Stat. Ann. \$11.441 (Supp. 1983); Ark. Stat. AnN. §§ 17-3601(5), 19-1705 (1980); Cal. Gov't Code § 26601 (West 1968 \& Supp. 1984); Colo. Rev. Stat. AnN. \$ 30-10-516 (1973); Del. Code Ann. tit. 11, §8302 (1974); Fla. Stat. Ann. § 30.15 (West 1974); Hawali Rev. Stat. §6-52-67 (1976); Ind. Code § 48-6107 (1950); Ky. Rev. Stat. AnN. $\$ 870.570$ (Baldwin 1970) (repealed 1978); Mass. ANN. LAws, ch. 41, 98 (Michie/Law Co-op. 1978); Md. Rev. Stat. \$85.060 (1952); Mich. Stat. AnN. \$82-1752 (Callaghan 1978); Mo. Rev. Stat. \$ 74.203 (1952) (repealed 1959); Neb. Rev. Stat § 16-323 (1977); N.D. Cent. Code \$ $11-15-$ 03 (Supp. 1983); Ohio Rev. Code AnN. \$ 737.11 (Page Supp. 1983); Utah Code AnN. \$§ 10-6-66 (1953), 17-22-2 (Supp. 1983); VA. Code § 15-1-138 (Supp. 1981); Wash. Rev. Code AnN. $\S 36.28 .010$ (Supp. 1984); W. VA. Code ANN. \$ 8-14-3 (1984).

56. See Conn. Gen. Stat. $\S 6-49$ (Supp. 1984); Ill. Ann. Stat., ch. 125, $\$ 82$ (Smith-Hurd Supp. 1984); Iowa Code $\S 748.6$ (1976); ME. Rev. Stat. AnN. tit. 15, § 704 (1964); Wyo. STat. § 7 $12-155$ (1959).

57. 249 lowa 297, 86 N.W.2d 829 (1957). Emmetsburg addressed the question whether the state or a locality was responsible for payment of police officers' medical expenses resulting from injuries incurred by officers while on duty. The state would only be responsible if the officers were acting in their official duties as law enforcement officers, in other words, actually enforcing the laws of the state. One of the officers had been injured when he slipped while checking parking meters. The other had tripped off a curb while inspecting locked doors. The court found that an officer's duty of law enforcement consists of every aspect or duty in the category of his work, whether hazardous or routine. Because the full enforcement statute required an officer to prevent breaches of the peace, 
statute, and it gives little guidance on the full enforcement question. In addition to the lack of case law, there has been only one Iowa Attorney General opinion on the duties of peace officers. ${ }^{58}$

The paucity of cases interpreting the full enforcement statutes is not peculiar to Iowa, and the few cases that do exist provide little in the way of doctrinal principles to guide interpretation of the clauses. ${ }^{59}$ The common thread running through these cases is that the full enforcement statutes are general rather than specific guidelines. In the cases which do address police discretion questions, there seems to be a general concern that when the police are confronted with flagrant misconduct, some action should be taken, even though that action need not be to arrest the offender. Two cases from California typify this approach.

In People v. Mullin, ${ }^{60}$ a sheriff was removed from office because he failed to investigate the complaint of a minor female that she had been molested by her father, despite the fact that the sheriff had been provided with corroborating evidence by an aunt and two other persons. ${ }^{61}$ Circumstances such as those in Mullin would offend the sensibilities of the citizenry of any community and the court may have been responding to strong public support to remove such a sheriff from office. ${ }^{62}$

In a less egregious situation, however, there is likely to be much less controversy over how a law enforcement officer exercises discretion as long as the officer does something. In People $v$. Spear, ${ }^{63}$ the court held that, in spite of clear and violent infractions of the picketing laws, a California sheriff had not exceeded his discretionary power by merely ordering the pickets to disperse rather than arresting the offenders. ${ }^{64}$

It appears as though the Mullin and Spear courts made an ad hoc analysis of the facts in each case, thereby determining whether the sheriff's actions warranted removal. These cases seem to typify courts' recognition that the police have some discretionary power in enforcing the law and are expected to exercise that discretion. It is clear, however, that the courts expect the police to do something; the police cannot refuse to act, especially when confronted with tangible evidence concerning violations of the law.

the court reasoned that, pursuant to this duty, the officer was on call at all times. Id. at 303-04, 86 N.W.2d at 834 .

58. In 1911 the Iowa Attorney General stated that it was within the powers of the sheriff to make arrest for gambling in the cities as well as in the counties and that municipal officers had no discretion to prevent the sheriff from carrying out his statutory duty. Op. Att'y Gen. 408-09 (Iowa 1911).

59. See infra note 69.

60. 197 Cal. App. 2d 479, 17 Cal. Rptr. 516 (1961).

61. Id. at 483, 17 Cal. Rptr. at 517-18.

62. For another example of a case in which a law enforcement officer was removed from office for violating community norms regarding acceptable levels of public behavior, see Larue v. Davies, 8 Cal. App. 750, 97 P. 903 (1908), in which removal of a town constable, who did not intervene to stop a street fight but simply let the participants continue to fight, was upheld.

63. 32 Cal. App. 2d 165, 89 P.2d 445, cert. denied, 308 U.S. 555 (1939).

64. Id. 
There are a few other cases which speak to the issue of selective enforcement of the law. In Gowan $v$. Smith, ${ }^{65}$ for example, the plaintiff sought a writ of mandamus to compel the police commissioner of Detroit to enforce a law prohibiting the operation of saloons on Sunday. The Michigan Supreme Court held that the writ of mandamus would not issue to compel the performance of discretionary acts of an executive kind, but only to require specific ministerial duties. ${ }^{66}$ The court explicitly recognized the need for discretionary decisionmaking by police officers, stating:

[T] he commissioner is bound to use the discretion with which he is clothed. He is charged not only with the execution of the liquor laws of the state within the city of Detroit, but he is likewise charged with the suppression of all crime and the conservation of the peace. . . . It is entirely obvious that he must exercise a sound discretion as to how those means shall be applied for the good of the community. ${ }^{67}$

It is important to note that the Supreme Court of Michigan in deciding the Gowan case did not refer for guidance to the Michigan full enforcement statute which was then in existence. ${ }^{68}$ The focus of the court was a local Detroit ordinance controlling and regulating establishments that sold liquor. ${ }^{69}$

The lack of case law interpreting the full enforcement statutes, as well as the likelihood that the language of the statutes might provide more explicit

65. 157 Mich. 443, 122 N.W. 286 (1909).

66. Id.

67. Id. at 473,122 N.W. at 297 .

68. See Act of 1895, ch. 215, 1895 Mich. Pub. Acts 215.

69. See 157 Mich. 443, 122 N.W. 286 (1909). Another case typical of those supporting the exercise of arrest discretion and which ignored the state "full enforcement" legislation is Taylor v. City of Pine Bluff, 226 Ark. 309, 289 S.W.2d 679, cert. denied, 352 U.S. 894 (1956). In Taylor the legislature, and by implication the police, were held to have the power to discriminate among similarly situated businesses in the enforcement of Sunday closing laws. Taylor, a Pine Bluff grocer, charged that the police adopted a policy of law enforcement instigated by the mayor and city council which resulted in the enforcement of state Sunday closing laws against grocery stores, but not against "drug stores, hotels, filling stations, restaurants, funeral homes; bakeries, tourist courts, bus stations, city park concessions, and sporting goods stores," despite the fact that the statute, Ark. Stat. $\$$ 41-3802 (1947), made it clear that it is a violation for any store to be open or to retail any goods or merchandise. Taylor, 226 Ark. at $310,289 \mathrm{~S} . \mathrm{W} .2 \mathrm{~d}$ at 680 . Taylor unsuccessfully made the argument that the enforcement policy of the police denied equal protection of the laws, as the other businesses sold many of the same items as did the grocery stores. $I d$.

In a decision clearly designed to support police discretion, the Arkansas Supreme Court rejected Taylor's claim and said: "It does not seem to us that the equal protection clause restricts the legislature to classifications based on the type of commodity being sold." Id. at $312,289 \mathrm{~S}$.W.2d at 681 . In an unusual opinion, the court went on to say that there might be reasonable grounds for the legislature to believe that "it is necessary and desirable to allow pharmacists to fill prescriptions on Sunday" and that the court "prefer[ed] to give full effect to the presumption of constitutionality that attends every statute and to uphold the statutory classification in the absence of proof indicating that there is no reasonable basis for the distinctions laid down by the legislature." Id.

The problem is that no distinctions were laid down by the legislature. The focus of the court was on what the legislature could do, not what they did. The issue in the case, however, was not the statute but how it was applied by the police, a point the court addressed only tangentially. The Arkansas Supreme Court apparently wanted to ensure that the police have sufficient power to exercise discretion in the arrest decision, but the court never directly addressed that issue, so we are uncertain as to the breadth of the power.

The principal state case cited in opposition to the argument that the police engage in law enforcement policymaking is Bargain City, Inc. v. Dilworth, $407 \mathrm{~Pa}$. 129, 179 A.2d 439 (1962). Bargain City was for all practical purposes a "Sunday Blue Laws" case, involving strong economic overtones, a fact scholars tend to overlook when discussing its ramifications. In Bargain City, the enforcement 


\section{direction to police officers, makes it important to analyze a typical full}

policy of the Police Commissioner of Philadelphia was attacked on the grounds that it was discriminatory in violation of the fourteenth amendment. Id. at 132, $179 \mathrm{~A} .2 \mathrm{~d}$ at 441 . Although the Pennsylvania Supreme Court did not resolve directly the claim of discriminatory enforcement, the court stipulated the following facts:

1) The Police Commissioner had established a policy of enforcing the Act only against employees of certain large retail establishments. 2) This enforcement policy was followed as a result of limited personnel. 3) There was no finding that the policy resulted from an evil or arbitrary design.

Id. at 134, $179 \mathrm{~A} .2 \mathrm{~d}$ at $44 \mathrm{l}$. Since the court declared that the issue of discriminatory law enforcement abated when the police chief left office, there was no actual determination of the validity of the enforcement policy. Nonetheless, Bargain City is frequently cited as the "bellweather" opinion prohibiting the development of selective enforcement policy. See Allen, supra note 2, at 112. Close analysis shows that the Bargain City holding is limited, however, primarily because of the subject matter of the case. Sunday Blue Law cases have strong equal protection overtones - the right not to be discriminated against solely on the basis of economic status. Bargain City dealt with an explicit policy to enforce the Sunday closing laws only against large department stores. Any arrest policy in which the decision to arrest is based solely on the economic status of the arrestee is constitutionally suspect. See LaFave, The Police and Nonenforcement of the Law (pt. l), 1962 Wis. L. REv. 104, 130 n.100. On the basis of the subject matter of the case and its limited, tangential discussion of police discretion, one can argue that the precedential value of Bargain City is quite limited.

Another case typical of those limiting law enforcement policymaking is State v. Lombardi, 8 Wis. 2d 421, 99 N.W.2d 829 (1959). In that case, the defendant was a sheriff who was found by a trial court to be guilty of willful dereliction of duty. The sheriff allegedly had reduced charges against some persons who initially were charged with driving under the influence of alcohol and had permitted violations of the state liquor and prostitution laws to go uncharged. Id. at 423-430,99 N.W.2d at 831-33. The opinion places substantial limitations on arrest discretion of law enforcement officers in Wisconsin.

The most recent case with direct relevance to the problems of law enforcement policymaking is Bruno v. Codd, 90 Misc. 2d 1047, 396 N.Y.S.2d 974 (1977), rev'd, 64 A.D.2d 582, 407 N.Y.S.2d 165 (1978), affd, 47 N.Y.2d 582, 573 N.E.2d 976, 419 N.Y.S.2d 901 (1979). In Bruno a group of 12 married women brought an action for declaratory and injunctive relief against the New York City Police Department, the Department of Probation, and Family Court. The women alleged that when New York City police officers were called to situations where a wife said she was being assaulted by her husband, the police uniformly refused to make an arrest, even if there was physical evidence of an assault. 90 Misc.2d at 1048, 396 N.Y.S.2d at 976. Instead of making an arrest, police informed the wives they were unable to act because of departmental policy permitting arrests only for violations of protection orders issued by the Family Court. Id. at 1049, 396 N.Y.S.2d at 976.

The question presented to the court was whether such action by the police as an abuse of police discretion. The concern was that the police had a virtually automatic rule which precluded arrest in any situation in which the victim was the wife of the assailant.

The case was heard by both a trial and an appellate court. At the trial court, the police and the other defendants requested summary judgment, which was denied. Id. at 1053,396 N.Y.S.2d at 979. The case was appealed and a decision was handed down approximately one year later reversing the decision of the lower court which had refused to dismiss the complaint. Bruno, 64 A.D.2d 582, 407 N.Y.S.2d 165 (1978).

In denying the motion for summary judgment, the trial court noted that it had the power to compel the police department defendants to perform the duty, which the law imposed upon them to exercise their discretion to arrest and to exercise it in a reasonable, non-arbitrary manner. Bruno, 90 Misc. 2d 1047, 396 N.Y.S.2d 974. The court found that police have a duty to protect battered wives, and that this duty might even be considered a "special duty" of protection. Id. at 1050,396 N.Y.S.2d at 977 . The court determined that the plaintiffs offered sufficient information to present a factual question as to whether, by the pursuit of a discriminatory policy, the police failed to perform their duty. Id.

In the interim, between dismissal of the motion for summary judgment and the appeal hearing, the police department entered into a consent decree with the plaintiffs. Bruno, 64 A.D.2d at 583, 407 N.Y.S.2d at 166 . While the consent decree called for greater enforcement of the assault statutes, it did recognize that the police must have the ability to exercise some discretion in the enforcement of 
enforcement statute. Such an analysis may increase the accuracy of the information as to the institutional constraints on the police. The Iowa full enforcement statute reads as follows:

Iowa Full Enforcement Statute

1. 748.4 Duties. It shall be the duty of a peace

2. officer and his deputy, if any, throughout the

3. county, township, or municipality of which he is

4. such officer, or to which he is assigned or employed

5. under any mutual assistance arrangement or

6. intergovernmental agreement, to preserve the peace,

7. to ferret out crime, to apprehend and arrest all

8. criminals, and insofar as it is within his power, to

9. secure evidence of all crimes committed, and present

10. the same to the county attorney, grand jury or

11. magistrate and to file informations against all

12. persons who he knows, or has reason to believe, to

13. have violated the laws of the state, and to perform

14. all other duties, civil or criminal, pertaining to

15. his office or enjoined upon him by law. Nothing

16. herein shall be deemed to curtail the powers and

17. duties otherwise granted to or imposed upon peace

18. officers. ${ }^{70}$

the criminal laws. One provision of the consent decree required officers to make an arrest upon the existence of reasonable cause to do so, but that provision applied only to felonies.

An officer must have justification for failing to arrest when reasonable cause exists to believe a husband has committed a misdemeanor against his wife, and he may not consider as justification the fact the victim is the wife of the misdemeanant, that she has no protection order, or that he thinks reconciliation is preferable. The reference to "justification" leaves the police with some discretion in deciding to arrest in misdemeanor cases and permits the development of some guidelines to determine whether arrest is appropriate, such as seriousness of injury and whether or not weapons were used.

The appellate court opinion in Bruno is also important. While that court decided that the consent decree between the police and the plaintiffs mooted the initial complaint, a close reading of the appellate case indicates that had there not been such a consent decree, the court would not have been as willing as the trial court to limit the discretion of the New York City Police Department. The appellate court was clearly disinclined to grant the relief sought because the issuance of an injunction would involve the court in what it viewed as an invasion of executive authority so broad as to be dangerously close to unconstitutionality. 64 A.D.2d at 583,407 N.Y.S.2d at 167.

70. Iowa CODE $\S 748.4$ (1975). For a discussion of what may have been one of the first full enforcement laws, see 2 L. Radzinowicz, A History of English Criminal LaW And Its Administration From 1750: The Clash between Private Initiative and Public Interest in the Enforcement OF THE LAW (1957), which indicates that in early years officers were fined for failure to enforce certain laws:

Twenty pounds for non-enforcement of the laws relating to hawkers and pedlars, bawdy houses, gaming-houses or disorderly houses not licensed for music and dancing. Two pounds for failure to attend the prosecution of persons bound on recognisances to appear, failure to apprehend persons throwing fireworks, to execute the summons of a justice, to report persons keeping alehouses without licenses, or to enforce certain laws relating to the armed forces. One pound for failure to assist the Officers of Customs and Excise, for failure to carry out the orders of a justice regarding vagrants or for neglecting to prosecute fraudulent bakers. . . . Ten shillings for neglect of duty relating to drunkenness, idle and disorderly persons, rogues and vagabonds; and to road offenses, including the depositing of rubbish in the streets. Five shillings for various instances of neglect in connection with the laws concerning the armed forces. Two shillings in a great variety of cases: for the non-enforcement of laws against profanity; for not apprehending lunatics when required to do so by a justice; for refusal to search for gun-powder; for failure to apprehend drivers of vehicles who misbehaved themselves; for failure to return a list of persons required to repair highways, or to apprehend persons committing nuisances, or to execute a warrant for a justice. 
The Iowa full enforcement statute was enacted in 1909, although some early Iowa statutes did speak of the sheriff as the conservator of the peace. ${ }^{71}$ A number of internal contradictions, gaps, and ambiguities arise in interpreting the statute. For example, on a first reading, especially of the operative phrase "apprehend and arrest all criminals," it would seem that a peace officer does not have the authority to refuse to make an arrest of a "criminal."72 The word "shall" in line 1 mandates that peace officers "apprehend and arrest all criminals."

One of the first questions is what construction should be given to the term "criminal," as used in the full enforcement statute. ${ }^{73}$ Judge Dillon, an eminent and often-quoted authority on municipal law writing around the time many of the full enforcement laws went into effect, appeared to distinguish between types of crimes, and obstensibly of criminals, by virtue of the distinction he found in the requirements of arrests for felonies and misdemeanors. ${ }^{74}$ Dillon indicated that the clear trend of the cases was that "[a]n officer is justified in arresting without a warrant upon a reasonable suspicion of a felony," even though the person did not commit the felony within the officer's view, but an officer cannot arrest a person for a misdemeanor without a warrant "unless there [is] a breach of the peace in his presence." 75 Thus, one could argue that, for purposes of interpretation of the statute, only a felon would be a "criminal" under the statute, and arrest directives, if they exist, only apply to felons. There is also clear evidence of an expectation of discretion in misdemeanor arrests. According to Judge Dillon, police officers had the authority

to arrest upon view intoxicated persons while guilty of disorderly conduct, or other persons violating the laws, and to detain them until they can be brought before a magistrate. If such an officer releases an intoxicated person, whom he had arrested while conducting himself in a disorderly manner, upon his promise to go directly home, he may lawfully retake him on his going into a bar-room before he is out of the officer's sight; and such arrest is justified, whether it be regarded as a recaption for the original purpose, or as a new arrest for disorderly conduct still continuing. ${ }^{76}$

Apparently Judge Dillon, a proponent of the view strictly limiting the

71. E.g., Iowa CoDE $\S 170$ (1851), originally applied only to sheriffs and their deputies. The section was in effect until 1927 , although the section number was changed frequently. See IOWA CODE $\S 383$ (1860); IOWA Code $\S 337$ (1873); Iowa Code $\S 472$ (1888); Iowa Code $\S 499$ (1897); Iowa CODE $\S 499$ (1913); IOWA CODE $\$ 5181$ (1924).

In 1927, the Forty-Second General Assembly amended the statute to include all peace officers and their deputies in addition to sheriffs and their deputies. Act of Feb. 22, 1927 (Chapter 122), 1927 Iowa Acts 115. The statute was repealed effective January 1, 1978, when the new Criminal Code was enacted in 1976 by the Sixty-Sixth General Assembly. Act of June 28, 1976 (Chapter 1245), ch. 4, §526, 1976 Iowa Acts 549, 774.

72. Since the word "criminal" is not defined in the code, one must make an assumption as to its meaning. A legitimate argument could be made that only the courts have the authority to determine who is a criminal and that until the courts have made that determination by virtue of a preliminary hearing and issued a warrant, peace officers are not required to "apprehend and arrest." However, it is likely that the choice of the word "criminal" was simply inappropriate and that the legislature intended for police to arrest anyone they had probable cause to believe had committed a crime.

73. See supra note 72.

74. 1 J. Dillon, Municipal Corporations $\S 210$ (4th ed. 1890).

75. Id. at 294-95 n.2 (emphasis in original).

76. Id. at 294-95 (emphasis in original). 
authority of municipalities and their officers, ${ }^{77}$ believed that the police were authorized to exercise discretion in the performance of their duties, particularly in making misdemeanor arrests, in spite of the specific admonishment of the full enforcement laws. Judge Dillon's views about the different treatment to be accorded misdemeanor violations becomes more important later. ${ }^{78}$

Problems of interpretation continue to arise when the statute is read as a whole. Arguments can be made that the mandates to (1) preserve the peace, (2) ferret out crime, (3) secure evidence of crime, and (4) perform all other duties, if strictly construed, conflict with the explicit requirement to "apprehend and arrest all criminals."

Consider the conflict between the phrases to "preserve the peace" and to "apprehend and arrest all criminals." Since the statute begins by requiring officers to "preserve the peace," that arguably would be the most important legislative objective. ${ }^{79}$ In fact, that was virtually the only duty included in the original Iowa full enforcement statute which was in existence for fifty-eight years. ${ }^{80}$ But what does the phrase mean? It conveys a general principle regarding the duties of law enforcement officers. It hardly can be classified as a specific command to apprehend and arrest all offenders. The most logical meaning is that officers are expected to exercise discretion and to refuse to make an arrest if such action would not "preserve the peace."

Ironically, the latter interpretation is consistent with a position taken by Professor Allen. ${ }^{81}$ He apparently is of the opinion that if an officer is faced with the situation in which an arrest is appropriate, yet such an arrest would cause a riot, the officer has the discretionary power not to make the arrest. To support his argument, he cites section 3.02 of the Model Penal Code and also concludes that his position is in accord with the common law. ${ }^{82}$ While the interpretation seems logical and appropriate, it does present some problems. In the full enforcement statutes adopted by eleven of the states which Allen cites, ${ }^{33}$ there is specific language which calls for the police not only to "preserve the peace" but also to "suppress all riots, affrays and insurrections." 84 Thus, under a strict interpretation of those statutes which Professor Allen

77. The "Dillon" rule on the interpretation of local government power is a "severe standard" and "even resolves reasonable doubts against the local government." $R$. LiNeBERRY \& I. Sharkansky, Urban Politics and Public Policy 106 (1974).

78. See infra notes $199-208$ and accompanying text.

79. At least one court explicitly recognized statutory inconsistency in requiring officers to execute the laws as well as to suppress crime and conserve the peace, and it concluded that the conflicting terminology must be construed as allowing police officers to exercise discretion. Gowan v. Smith, 157 Mich. 443, 473, 122 N.W. 286, 297 (1909).

80. W. Jackson, supra note 38 , at $26-27$; see supra note 71 .

81. Allen, supra note 2, at 114-15.

82. Id.

83. See id. at 71 n.48; see also supra note 49 .

84. Ariz. Rev. Stat. Ann. § $11-441$ (1956); Ark. Stat. AnN. § 19-1750 (Supp. 1960); Cal. Gov't Code $\$ 26602$ (West 1968); Colo. Rev. Stat. AnN. \$ 31-4-112 (1973); Del. Code AnN. tit. $11, \S 8302$ (1974); Fla. Stat. Ann. $\$ 30115$ (West 1979); Idaho Code $\S 11-15-03$ (1975); Mass. Ann. Laws, ch. 41, § 898 (Michie/Law. Co-op. 1973); Mich. Stat. Ann. \$ 85-1752 (Callaghan 1949); N.D. Cent. Code $\S 1115-03$ (1960); Wash. Rev. Code AnN. $\$ 36.28 .010$ (1975). 
suggests elsewhere, ${ }^{85}$ this statement that the police may refuse to arrest a person if such arrest would cause a riot would seem to be in error. According to a strict reading of the full enforcement statutes, police are required both to arrest all criminals and to suppress all riots. But it is obvious that Professor Allen's quite liberal interpretation that the police are not to make arrests if to do so would cause a riot is a more plausible approach. Yet, such an approach clearly requires the police to make a policy judgment, in direct conflict with the explicit language of the statutes.

These are not the only problems that arise from a strict construction of the statutes. For example, as noted above, the Iowa requirements to "ferret out crime" and "to secure evidence of all crimes committed" could, if read strictly, conflict with the duty to "apprehend and arrest all criminals." It is common for law enforcement agencies to be involved in investigations covering long periods of time during which information regarding law violations come to the knowledge of the police. ${ }^{86}$

Two important questions must be considered here. First, do the police have discretion to delay in making an arrest? Second, do police have the discretion to forego arrest altogether in return for cooperation? In an investigation of illegal drug trade, for example, the police might obtain evidence showing minor criminal violations by relatively insignificant members of a drug ring, but they may defer or totally forego their arrest in order to avoid alerting major suppliers and distributors who might escape. Immediate or even ultimate arrest of minor violators might defeat the main purpose-to arrest the major suppliers and distributors and to break up the ring. In other words, can the police decide to focus on major as opposed to minor violators? Removing major violators certainly seems to advance the primary legislative goal of "preserving the peace."

Finally, a strict reading of the statute creates additional problems of viewing it as establishing only ministerial duties. In lines 13 and 14 there are statutory provisions calling for peace officers "to perform all other duties civil or criminal." In Iowa, peace officers have had over the years a number of duties which clearly require the exercise of some discretion. ${ }^{87}$ Therefore, we return to the question of how strictly the language of the statute should be construed. Canons of statutory construction would argue against treating explicit statutory language as irrelevant. ${ }^{88}$ Furthermore, in many of the full enforcement statutes the mandate to "preserve the peace" is the first law

85. Allen, supra note 2 , at 73 .

86. Des Moines Register, Dec. 16, 1982, at 1, col. 2.

87. See W. Jackson, supra note 38 , listing the following such duties:

(1) Execute writs of attachment. The sheriff shall in all cases attach the amount of property directly, if sufficient property not exempt from execution is found in his county, giving that in which the defendant has a legal and questionable title a preference over that in which the title is doubtful or only equitable. (2) Conduct sheriff's sale. (3) Keep the jail. (4) Collect delinquent taxes by distress and sale. (5) Select jury in condemnation cases and receive and administer money payments.

Id. at 19-36.

88. IOWA CODE $\S 4.6(1981)$. 
enforcement duty assigned. ${ }^{89}$ Construing the phrase as irrelevant would be tantamount to asserting that the legislature did not intend to list "preserve the peace" as a duty of the police officer-an undoubtedly tortured construction.

The most reasonable interpretation of the phrase "preserve the peace" assumes that the legislature intended the police to do more than rigidly apply the laws. The phrase "preserve the peace," in the context of most of the statutes, clearly implies that the police are expected to exercise some discretion in the enforcement of the laws, and that their paramount duty is not full enforcement but maintenance of order and prevention of crime. ${ }^{90}$

The language, "to apprehend and arrest all criminals," when read alone, establishes a concrete duty to arrest all persons who have committed a crime. However, when read in conjunction with the rest of the statute, the phrase must be construed as a statement of policy, requiring the police to arrest when arrest serves the general purposes of the law-to preserve the peace. Sound judgment compels a reading of the statutes more as policy statements than as explicit legislative commands.

The idea that the statutes were intended to be policy statements is reinforced by a review of the status of law enforcement nationwide at the time those statutes were promulgated. Law enforcement by sheriffs was lax. One writer, attempting to analyze the office of the sheriff in Iowa in the early 1900 's, contends that the statute was made specific to encourage sheriffs to become more active in law enforcement than they had been in the past. ${ }^{91}$ Because sheriffs were assigned many other duties which were financially more rewarding than law enforcement, there was little interest among the sheriffs in becoming active law enforcement officers. ${ }^{92}$ The same objective, to encourage sheriffs to become more active in law enforcement, seems to have existed in Ohio. An Ohio full enforcement statute provided that:

Each sheriff shall preserve the public peace and cause all persons guilty of breach thereof, within his knowledge or view, to enter into recognizance with sureties to keep peace and to appear at the succeeding term of the common pleas court of the property county and commit them to jail in case of refusal. ${ }^{93}$

In spite of this "full enforcement" provision, there was a general attitude among the Ohio sheriffs that this duty could be avoided, and apparently there were "few successful prosecutions" of sheriffs who failed fully to enforce the law. ${ }^{94}$ In fact, police scholars have found that sheriffs in the United States at

89. R. Fosdick, supra note 43, at 53-54. Along with Iowa, the full enforcement statutes of Arizona, California, Delaware, Florida, Idaho, Indiana, Kentucky, North Dakota, Ohio, and Utah list preserving the peace as the first law enforcement duty of peace officers. See also supra note 51 \& text accompanying note 79 .

90. R. Fosdick, supra note 43 , at 53-54.

91. W. Jackson, supra note 38 , at 27.

92. B. Smith, The State Police: Organization And Administration 16-19 (1925).

93. Ohio Rev. Code Ann. § 2833 (Page 1954).

94. R. Heiges, The Office of Sheriff in the Rival Counties of Ohio 15 (1933) (unpublished Ph.D. dissertation, Department of Political Science, Columbia University) (quoting A. LASHLY, THE ROAD to Prison: Proceedings of the American Prison Association 384-85 (1928)). 
that time generally considered the law enforcement aspects of their jobs to be very unimportant and that few sheriffs took their law enforcement tasks seriously. ${ }^{95}$

A similar case can be made in considering those full enforcement statutes that are directed primarily toward local police departments. As we have seen, many of those "full enforcement" statutes were promulgated around the same time that control of the police and many other municipal functions were returning to the local communities. ${ }^{96}$ Consequently, it seems appropriate to view the grants of power returning control of the police to the local communities (of which the full enforcement statutes were frequently a part) primarily as expressions of the general duties and responsibilities of the police. The statutes were to guide local communities in further refining and developing the proper role of the police. As the previous analysis suggests, there is difficulty in interpreting the statutes as anything more than policy statements.

If such statutes were to be considered otherwise, it would be impossible to give them full effect. Thus, to the extent that the full enforcement clauses are, or have been, important in the consideration of the role of the police in the United States, they have to be considered as general policy statements. In fact, one can argue that the general nature of those policy statements conveys an implicit understanding of the need for police to be able to exercise some discretion in carrying out their law enforcement duties.

\section{III}

\section{Separation of Powers}

The preceding analysis shows the police to be a peculiar organization, which does not fit neatly into any particular category of government agency. Many municipal police officers are hired according to state guidelines, ${ }^{97}$ enforce state law, and have their duties prescribed by the state legislators; 98 yet they are selected, funded, and supervised by municipal governments. ${ }^{99}$ While the involvement of so many different government institutions and agencies would seem to anticipate a closely supervised agency, the practical result, in most parts of this country, is a truly independent bureaucracy.

Even if one were to conclude that the full enforcement statutes implicitly recognize this unusual situation and expect discretion to be exercised by the police, there are still other questions concerning the legality of law enforcement policymaking. Professor Allen has argued "that substantive rulemaking lies in the face not only of the language of the full enforcement statute, but also the concept of government that the statutes manifest: the principle of

95. B. Smiтh, supra note 92 , at 16-19, 26-27.

96. See supra note 53.

97. See, e.g., Iowa Code $\& 80 \mathrm{~B}$ (1981).

98. See supra note 51 for a listing of state statutes that describe duties of state and local law enforcement officers.

99. See, e.g., Iowa CoDE $\S 372$ (1981). 
separation of powers."100 At least two questions regarding separation of powers must be addressed. First, do the full enforcement statutes, which according to my view contemplate discretion, violate state separation of powers provisions? Second, even if the full enforcement statutes do not contemplate discretion, does any statute authorizing or contemplating the exercise of police discretion violate state separation of powers principles?

The principles of separation of powers are clearly enunciated in the federal and most state constitutions. ${ }^{101}$ Typical of such state provisions is the language found in the Iowa Constitution:

The powers of the government of Iowa shall be divided into three separate departments - the Legislative, the Executive, and the Judicial; and no person charged with the exercise of powers properly belonging to one of these departments shall exercise any function appertaining to either of the others, except in cases hereinafter expressly directed or permitted. ${ }^{102}$

The primary difference between federal and state constitutions is that the latter frequently have tended to be more explicit in expressing the theory that one branch of government should not exercise the power of another. ${ }^{103}$ Those who criticize the development of formal law enforcement rules essentially have taken the position that the development of such rules is, in effect, a usurpation of the legislative function by the executive branch and therefore a constitutional violation. ${ }^{104}$

As the constitution drafters realized, the essence of democratic government mandates that separation of powers be maintained. ${ }^{105}$ The question, however, is whether the separation of powers doctrine requires rigid adherence or expresses an ideal which government should seek to achieve. In other words, does it express specific or general limitations on government? Other constitutional provisions and American history seem to indicate it is the latter rather than the former.

Drafters of the United States Constitution, for example, while expressing the separation of powers principles in that document, did not rigidly adhere to it throughout their work. The Constitution clearly requires the executive branch to review and monitor some of the work of other branches and vice versa. The President has the power "to grant Reprieves and Pardons for Offenses"' 106 made crimes by the U.S. Congress, to negotiate treaties, ${ }^{107}$ and

100. Allen, supra note 2, at 75-76.

101. Id. at $76 \mathrm{nn} .63,65$.

102. Iowa Const. art. $3, \S 1$.

103. Allen, supra note 2 , at 76-77.

104. See id. at 98 ; Goldstein, supra note 48 , at $586-87$.

105. The Federalist No. 47 (J. Madison) (C. Van Doren ed. 1945) [hereinafter cited as ThE FEDERALIST] expresses the practical view of the separation of powers doctrine. The political philosophers Locke and Montesquieu, who contributed greatly to the theoretical development of the concept of separation of powers, however, were not overly concerned with its practical effect. Unfortunately this was a concern the Constitutional Convention would not avoid. For the philosophical view, see B. Montesquieu, The Spirit of the Law 15 I-62 (T. Nugent trans. 1949); J. Locke, Of Civil. Government 124-34 (2d Gateway ed. 1962); W. Bondy, The Separation of Governmental Powers 12-14 (1967).

106. U.S. Const. art. II. $\$ 2, \mathrm{cl} .1$.

107. Id. art. II, $\S 2$, cl. 2. 
in extraordinary cases to convene the Congress. ${ }^{108}$ The U.S. Congress similarly has the power to disapprove certain presidential appointments, ${ }^{109}$ to remove executive officers through the impeachment process, ${ }^{10}$ and to override presidential vetoes. ${ }^{11}$ What we have come to recognize in America is that no single branch of government possesses exclusive authority to act in any one area.

The framers of the United States Constitution apparently did not view the separation of powers doctrine as rigid and inflexible. They clearly intended, and in fact provided for, overlapping powers. They were persons with considerable practical political experience. Their primary goal in allocating power and authority was to avoid the location of too much power in any one branch of government. 112

The Federalist No. 47 clearly states the pragmatic principles underlying the Framers' view of separation of powers. That essay essentially reinterprets Montesquieu's position, that "there can be no liberty, where the legislative and executive powers are united in the same person . . .,"113 by adding:

$[\mathrm{H}] \mathrm{e}$ [Montesquieu] did not mean that these departments ought to have no partial agency in, or no control over the acts of each other. His meaning, as his own words import, and still more conclusively as illustrated by the example in his eye, can amount to no more than this, that where the whole power of one department is exercised by the same hands which possess the whole power of another department, the fundamental principles of a free constitution are subverted. 114

Obviously, the drafters of the Constitution were much more concerned than was Montesquieu with the practical impact of the doctrine of separation of powers on the normal operation of government. There was expected to be some overlap of power in the functioning of government.

The U.S. Constitution, as well as most state constitutions, has recognized the inherent difficulty of attempting rigidly to classify powers as legislative, executive, or judicial. The courts, rather than trying to divide the powers sharply, have tended to stress that the differences are frequently those of degree rather than kind. For example, Mr. Justice Holmes, in his dissenting opinion in Springer $v$. Phillippine Islands, ${ }^{15}$ stated:

The great ordinances of the Constitution do not establish and divide fields of black and white. Even the more specific of them are found to terminate in a penumbra shading gradually from one extreme to the other.

It does not seem to need argument to show that however we may disguise it by veiling words we do not and cannot carry out the distinction between legislative and executive action with mathematical precision and divide the branches into watertight

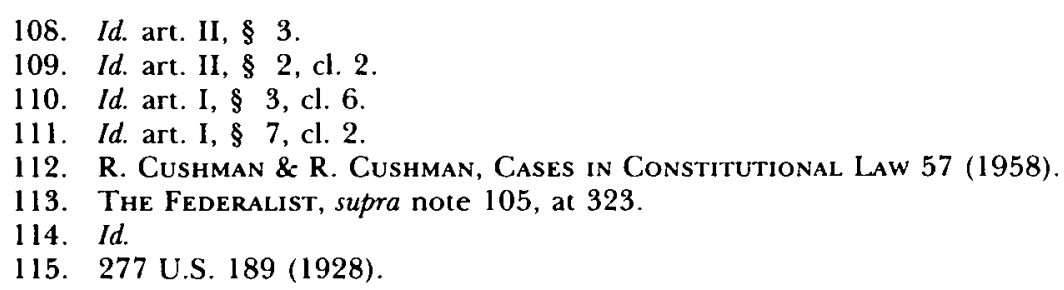


compartments ... which I am far from believing... that the Constitution requires. ${ }^{116}$

More recently, Mr. Justice Jackson reaffirmed Mr. Justice Holmes's position. In Youngstown Sheet $\mathcal{E}^{2}$ Tube Co. $v$. Sawyer, ${ }^{117} \mathrm{Mr}$. Justice Jackson stated in a concurring opinion:

While the Constitution diffuses power the better to secure liberty, it also contemplates that practice will integrate dispersed powers into a workable government. It enjoins upon its branches separateness, but, interdependence, autonomy but reciprocity. ${ }^{118}$

The primary concern underlying the doctrine of separation of powers at the federal level is that no single branch of government wield excessive power, not that the executive exercise no legislative power or vice versa.

The approach to separation of powers at the state level was somewhat different. In what could be characterized as an anomalous approach, state constitutions, while frequently tending to be more explicit in stating the doctrine, were less inclined to follow it. ${ }^{19}$ The separation of powers provisions, although expressed formally, were not given great deference when the drafters came to the business of distributing power. Particularly significant is the fact that in early state constitutions the legislatures were given substantial amounts of executive and administrative control. ${ }^{120}$ As the court in People ex rel. Kern v. Chase ${ }^{121}$ said:

We are not unmindful of the well settled ruled that there are many cases in which ministerial officers exercise quasi judicial powers or discretions and yet the laws conferring such powers are held to be no violation of the constitutional provision under consideration. ${ }^{122}$

The vesting in the legislative bodies of substantial power other than to make laws was largely a reaction to the excessive power exercised by colonial administrators. ${ }^{123}$ Thus, as far as the principle of separation of powers is concerned, there was a clear contradiction in many state constitutions. While recognizing and expressing the doctrine of separation of powers, many constitutions clearly established the legislature as the most powerful branch of the government.

Over the long term, however, this distribution of power did not result in

116. Id. at 209-11 (Holmes, J., dissenting).

117. 343 U.S. 579 (1952).

118. Id. at 635 (Jackson, J., concurring). See generally Hampton \& Co. v. United States, 276 U.S. 394, 406 (1928); United States v. Nixon, 418 U.S. 683,707 (1974); Buckley v. Valeo, 424 U.S. 1, 120 22 (1976); Nixon v. Administrator of Gen. Servs., 433 U.S. 425, $441-44$ (1977); United States v. American Tel. \& Tel. Co., 567 F.2d 121 , 127-28 (D.C. Cir. 1977); Olegario v. United States, 629 F.2d 204, 226-27 (2d Cir. 1980), cert. denied, 450 U.S. 980 (1981); Chadha v. Immigration \& Naturalization Serv., 634 F.2d 408, 424-25 (9th Cir. 1980) (defining a "judicial standard" for determining violations of the separation of powers doctrine), affd, 462 U.S. 919 (1983); United States v. Mississippi Power \& Light Co., 638 F.2d 899, 906 n.12 (5th Cir.), cert. denied, 454 U.S. 892 (1981); F. Frankfurter, The Public and its Government 77-79 (1930); The Federalist, supra note 105.

119. See, e.g., F. GreEN, supra note 40 , at 83 .

120. J. Dealey, supra note 36 , at $8 \mathrm{n} .1,243$.

121. 165 III. 527,46 N.E. 454 (1896).

122. Id. at 541, 46 N.E. at 459. Chase is discussed in F. Goodnow, Selected Cases on GovernMENT AND ADMINISTRATION 25 (1906).

123. See F. Green, supra note 40, at 91; J. Dealey, supra note 36 , at 160. 
the emergence of the legislature as the dominant policy-maker in state government. As we will see in the next part of this article, the practical needs of modern society have required that the legislature and the executive share policymaking to ensure the efficient operation of government. Consequently, many constitutions were amended as there developed "a strong centralizing tendency in economic and political life" which resulted in greater focus on the role of the state executives. ${ }^{124}$ As a general proposition, the pressing need for the sharing of executive and legislative authority has been embraced and, in fact, welcomed. ${ }^{125}$ This development has caused one writer to state that "the history of the separation of powers doctrine has apparently been one of rapid retreat, if not rout." 126

The historical evolution of the separation of powers doctrine sketched above clearly supports the concept of dividing policymaking power among the branches of government. It is clear, as recognized by Madison, that there was a danger inherent in vesting absolute policymaking power in one branch of government. ${ }^{127}$ Thus, the idea that the state legislature has absolute power in controlling the administration of the criminal laws is contrary to the normal operation of federal and state government. In conclusion, it seems that arguments that substantive rulemaking is inconsistent with separation of powers ignore three things: 1) the uncertain boundary between substance and procedure, 2) the necessity of administrative discretion to carry out any complex statute, and 3) courts' long recognition of the impossibility of legislative prescience and foresight. This inconsistency will be reinforced below by an analysis of the principle of delegation of powers and how it fits into the separation of powers concept.

\section{IV}

\section{Delegation}

The separation of powers doctrine is given greater meaning by a close look at the principle of delegation of power. We have found in the United States that the delegation of power to executive and administrative agencies is absolutely essential to the operation of government. ${ }^{128}$ Therefore, it is important to gain a general understanding of that principle and how it has evolved on both the federal and state levels. More specifically, the task is to determine whether or not law enforcement policymaking by the police is permissible as a matter of federal and state constitutional law.

Again, we see a different approach taken by our two main protagonists. Professor Davis asserts there is substantial support for the proposition that

124. J. DEALEY, supra note 36 , at 160 .

125. R. Highsaw, The Government and Administration of Mississippi 5 (1972); C. Ransone, The Office of Governor in the United States 160 (1970).

126. 1 F. Cooper, State Administrative Law 15 (1965).

127. The Federalist No. 48 (J. Madison).

128. K. Davis, Administrative Law Text 36-4l (3d ed. 1972). 
the police can engage in rulemaking. ${ }^{129}$ Essentially, his position is that administrative agency officials are expected to amass a special expertise in their work and to use that expertise by developing rules and standards to control the activities of their subordinates. ${ }^{130}$ He maintains further that courts generally have given deference to the exercise of this expertise and that the same deference should be given to police executives. ${ }^{131}$ According to Davis, government agencies require a broad mandate to enable them to perform their duties, and this mandate necessarily includes the authority to develop rules. ${ }^{132}$

Professor Allen, on the other hand, sees the permissible scope of delegated power as much more restricted. Because of the penal nature of the criminal law, Allen contends that delegation of policymaking power to police agencies is substantially limited. ${ }^{133}$ Furthermore, he claims that the federal court cases cited by Professor Davis have very little support on the state level. ${ }^{134}$ Finally, Allen asserts that delegation of legislative power concerning criminal law has been permitted on the state level only in limited and carefully defined circumstances, and that the exercise of law enforcement policymaking would not fall within those limitations. ${ }^{135}$

Largely because of the ever-increasing complexity of our society, the principle of delegation of power has been evolving constantly. Initially, the U.S. Supreme Court had a very narrow view of the proper boundaries of delegated power, ${ }^{136}$ as evident in cases like Field $v$. Clark. ${ }^{137}$ It quickly became clear, however, that limiting the executive function solely to fact-finding hampered administrators in carrying out the required work of government; consequently, Congress increased the responsibility of administrative agencies, and the courts permitted broader delegation of legislative power.

The Supreme Court case of Wayman v. Southard ${ }^{138}$ signaled the beginning of this trend. In Wayman, Chief Justice Marshall made it clear that the Congress had the power to delegate powers which were not strictly and exclusively legislative. But it was eighty-five years before there was elaboration of how far Congress might go. In United States $v$. Grimaud, ${ }^{139}$ the Supreme Court reviewed a statute ${ }^{140}$ establishing forest reservations on public lands. The statute gave the Secretary of Agriculture power to make rules to regulate the use and occupancy of reservations and stipulated that violators of the rules

129. K. Davis, supra note 1, at 107-12.

130. Id.

131. Id.

132. Id.

133. Allen, supra note 2 , at 88 .

134. Id.

135. Id. at 90 .

136. Note, Safeguards, Standards and Necessity: Permissible Parameters for Legislative Delegations in Iowa,

58 Iowa L. Rev. 974, 976-77 (1973).

137. 143 U.S. 649 (1892).

138. 23 U.S. (10 Wheat.) 1 (1825).

139. 220 U.S. 506 (1911).

140. Act of March 3, 1891, ch. 561, 26 Stat. 1103. 
promulgated by the Secretary were subject to criminal sanctions. The Supreme Court held that this grant of power was not an invalid delegation of legislative power. ${ }^{141}$

The Court reasoned that the legislature was the body making the acts criminal and establishing the penalty; the Secretary was merely determining the facts of a given situation and applying the law to them. ${ }^{142}$ We see that at a very early stage the Supreme Court established that it is within the legislature's power to delegate to the executive branch the authority to make rules to carry out the legislative purpose of a statute. In fact, it might be noted that Field v. Clark and the other early Supreme Court delegation cases were unrealistic descriptions of the administrative process even at that time. For example, to look at the foreign affairs function delegated expressly to the President in the nineteenth century as being merely mechanical would be misleading no matter how the court describes that function.

The federal courts increasingly have upheld both explicit and implicit granting of power and authority by Congress to administrative agencies. ${ }^{143}$ In fact the situation may be as one scholar suggests: "Every statute is a delegation of lawmaking power to the agency appointed to enforce it." 144 It is this evolution of power that Professor Davis looks to for support of his theory. ${ }^{145}$

\section{A. Federal Delegation}

Professor Davis cites the case of Skidmore $v$. Swift ${ }^{146}$ as establishing the proposition that agency heads are expected to develop a special expertise in their work. Skidmore was a case brought under the Fair Labor Standards Act. ${ }^{147}$ An important issue in Skidmore was the degree of deference courts should accord to the administrator of the Wage and Hour Division in the interpretation of the Act. The issue arose because there was no statute or previous case which stipulated what, if any, deference courts should give to the administrator's findings. The Supreme Court held that

the Administrator's policies are made in pursuance of official duty, based upon more specialized experience and broader investigations and information than is likely to come to a judge in a particular case. . . . We consider that the rulings, interpretations and opinions of the Administrator under this Act, while not controlling upon the courts by reason of their authority, do constitute a body of experience and informed judgment to which courts and litigants may properly resort for guidance. ${ }^{148}$

According to Davis, the recognition by the Supreme Court of specialized experience possessed by administrators is significant and has direct relevance

141. Grimaud, 220 U.S. 506.

142. Id. at 522-23. Grimaud has not been overruled. See Singer v. United States, 323 U.S. 338 , 345-46 (1945); United States v. Cassiagnol, 420 F.2d 868, 875-77 (4th Cir.), cert. denied, 397 U.S. $1044(1970)$.

143. K. Davis, supra note 128 , at 26-28.

144. L. Jaffe, Judicial Control of Administrative Action 35 (1965).

145. K. Davis, supra note 1, at 103-12.

146. 323 U.S. 134 (1944).

147. 29 U.S.C. $\$ \S 203,207$ (1982).

148. 323 U.S. at $139-40$. 
to the work of law enforcement officers. ${ }^{149}$ The fact that law enforcement work frequently requires the ability to deal with complex and difficult personal and societal problems would seem to support Davis's view. The diversity of situations to which law enforcement agencies respond requires that the police develop a wide variety of strategies and tactics to ensure that public safety is maintained, while individual rights are not violated. If this work is done poorly or improperly, it can have substantial repercussions on the body politic. It seems beyond argument that law enforcement officials similar to those of the Wage and Hour Division in Skidmore $v$. Swift are expected to develop an understanding of likely problems in their areas of work. ${ }^{150}$

Of course, there is a substantial difference between developing expertise in an area and being permitted to use that expertise to produce and to put into effect enforcement strategies. Nonetheless, the Supreme Court of the United States, according to Professor Davis, has taken that next step and held that it is entirely proper for the courts in appropriate circumstances to defer to the expertise of agency heads in developing enforcement strategies. He argues that Moog Industries $v$. FTC ${ }^{151}$ recognizes the complex policymaking functions that many administrative agencies face. ${ }^{152}$

The Moog Industries Court addressed the issue of whether the court of appeals could postpone a valid cease and desist order of the Federal Trade Commission. Moog Industries claimed the order unfairly discriminated against it in that it "would suffer serious financial loss if prohibited from engaging in pricing practices open to its competitors." 153 The Supreme Court held the Federal Trade Commission alone was empowered to develop the enforcement policy best calculated to achieve the ends contemplated by Congress. In essence, the Court found that in formulating enforcement policy, an administrative "agency is called upon to exercise its specialized, experienced judgment."154 According to Allen, the important fact for the Court was that there was no allegation that the FTC was unprepared to move against other violators of the statute, and thus the issue of selective enforcement was not squarely before the Court. ${ }^{155}$

While Professor Allen may be correct technically in that the issue of selective enforcement was not directly before the Court, his interpretation of Moog

149. K. Davis, supra note 1, at 108-10.

150. See id. at 137-38. Following Skidmore, courts have shown exceptional deference to the construction of a statute by the administrative agency charged with enforcing the statute. See, e.g., NLRB v. Boeing Co., 412 U.S. 67, 75 (1973); United States v. Consumer Life Ins. Co., 430 U.S. 725, 751 -52 (1977); Good Samaritan Hosp., Corvallis v. Matthews, 609 F.2d 949, 954-55 (9th Cir. 1979); Eirhart v. Libbey-Owens-Ford Co., 616 F.2d 278, $281-82$ (7th Cir.) (and cases cited therein), cert. denied, 449 U.S. 828 (1980). As to an agency's interpretation of its own administrative regulation, see Udall v. Tallman, 380 U.S. 1, 16-17, reh'g denied, 380 U.S. 989 (1965) (citing Bowles v. Seminole Rock Co., 325 U.S. 410, 413.14 (1945)); Montana Power Co. v. EPA, 608 F.2d 334, 344, 348 \& n.27 (9th Cir. 1979).

151. 355 U.S. 411 (1958).

152. Id.

153. Id. at 412 .

154. Id. at 413.

155. Allen, supra note 2, at 112-14. 
minimizes the language of the opinion indicating the breadth of discretion properly delegated to the Federal Trade Commission to formulate enforcement policies. According to the Court:

Only the Commission, for example, is competent to make an initial determination as to whether and to what extent there is a relevant "industry" within which the particular respondent competes and whether or not the nature of that competition is such as to indicate identical treatment of the entire industry by an enforcement agency. Moreover, although an allegedly illegal practice may appear to be operative throughout an industry, whether such appearances reflect fact and whether all firms in the industry should be dealt with in a single proceeding or should receive individualized treatment are questions that call for discretionary determination by the administrative agency. ${ }^{156}$

The development of case law since Moog Industries seems to rely on, and to reinforce, the rule that administrative agencies have discretion to determine against whom they will enforce the laws-discretion that goes beyond the mere allocation of resources. The U.S. Supreme Court has continued to address the issue of the establishment of enforcement policy by administrative agencies.

In FTC v. Universal-Rundle Corp., ${ }^{157}$ the Commission found the corporation to have violated section 2 of the Clayton Act $^{158}$ by discriminating in price between customers, and issued a cease and desist order prohibiting that practice. The respondent petitioned the Commission to stay its cease and desist order pending investigation of alleged industry-wide discount practices, claiming that enforcement against it alone would cause it substantial financial injury. After the FTC denied the petition, respondent instituted review proceedings in the Court of Appeals for the Seventh Circuit. The court, finding the Commission's denial of the stay to have been a "patent abuse of discretion" in light of respondent's evidentiary offering, set aside the Commission's order. The court also instructed the Commission to conduct an investigation to determine whether industry-wide proceedings might not be more appropriate than proceeding solely against the respondent. ${ }^{159}$

On appeal, the Supreme Court reversed the court of appeals' finding of a "patent abuse of discretion," and specifically held that the Commission's denial of respondent's petition was appropriate because the respondent's evidence did not prove that practices of the respondent's competitors had an anti-competitive effect. ${ }^{160}$ More significantly for this analysis, the Court stated that

even if a petitioner succeeded in demonstrating to the Commission that all of its competitors were engaging in illegal price-discrimination practices identical to its own, and that enforcement of a cease-and-desist order might cause it substantial financial injury, the Commission would not necessarily be obliged to withhold enforcement of the order. As we stated in Moog . . . "the Commission alone is empowered to develop that enforcement policy best calculated to achieve the ends contemplated by Congress

156. Moog Industries, 355 U.S. at 413.

157. 387 U.S. 244 (1967).

158. 15 U.S.C. $\$ 13$ (1982).

159. See Universal-Rundle, 387 U.S. at 246-49.

160. Id. at 250-51. 
and to allocate its available funds and personnel in such a way as to execute its policy efficiently and economically." 161

The principle of deference to agency enforcement policy was also affirmed in the case of Butz v. Glover Livestock Commission Co. ${ }^{162}$ In Butz, the Court of Appeals for the Eighth Circuit, after finding that the Judicial Officer of the Department of Agriculture had improperly issued a cease and desist order against respondent for willful violation of the Packers and Stockyards Act, ${ }^{163}$ had set aside the Department's twenty-day suspension of respondent's registration under the Act. ${ }^{164}$ According to the court of appeals, the suspension order was "unconscionable" because the resulting sanction was too severe and the issuance of the suspension order, in respondent's case, was contrary to a policy of "achiev[ing] ... uniformity of sanctions for similar violations." 165

The Supreme Court granted certiorari and found that the proper standard of judicial review of the Department's suspension order must accord with the "fundamental principle . . . that where Congress has entrusted an administrative agency with the responsibility of selecting the means of achieving the statutory policy the relation of remedy to policy is peculiarly a matter of administrative competence." 166 Following that standard, the Supreme Court reversed the decision of the court of appeals, holding that, because the Department's suspension order was not "unwarranted in law" or "without justification in fact," the Department had full authority to issue the order. ${ }^{167}$

161. Id. at 251 (quoting Moog Industries v. FTC, 355 U.S. 411,413 (1958)).

162. 411 U.S. 182 (1973).

163. 7 U.S.C. $\$ \$ 181-229$ (1982).

164. See Butz, 411 U.S. at 183.

165. Glover Livestock Comm'n Co. v. Hardin, 454 F.2d 109, 115 (8th Cir. 1972), rev'd sub nom. Butz v. Glover Livestock Comm'n Co., 411 U.S. 182 (1973).

166. Butz, 411 U.S. at 185 (citing American Power \& Light Co. v. SEC, 329 U.S. 90,112 (1946)).

167. Butz, 411 U.S. at 185-89. There are other cases at the federal level which continue to follow the rationale of Moog Industries v. FTC, 355 U.S. 411 (1958); see supra notes 151-56 and accompanying text. In Jewel Cos. v. FTC, 432 F.2d 1155 (7th Cir. 1970), the Federal Trade Commission conducted proceedings pursuant to a complaint alleging violations of the Robinson-Patman Act. Moog Industries was cited for the proposition that the courts have no jurisdiction to interfere with the discretion of the Commissioner in issuing complaints. 432 F.2d at 1160 . In L.G. Balfour Co. v. FTC, 442 F.2d 1 (7th Cir. 1971), an FTC order against the plaintiff for unfair methods of competition was upheld. Both the Moog Industries holding that a cease and desist order against only one firm in a context of industry-wide abuse is valid and that case's view of an agency's expertise and the need for latitude to form orders that best serve its congressionally appointed function were cited with approval. 442 F.2d at 24. In Glover Livestock Comm'n Co. v. Hardin, 454 F.2d 109 (8th Cir. 1972), rev'd sub nom. Butz v. Glover Livestock Comm'n Co., 411 U.S. 182 (1973), see supra text accompanying notes 162-64, the Secretary of Agriculture issued a cease and desist order for violation of the Packers and Stockyards Act, 7 U.S.C. $\S \S 181-229$ (1982), and suspended the defendant's registration. Moog was cited for its dictum concerning the provence of an agency to act within the area of its expertise. $454 \mathrm{~F} .2 \mathrm{~d}$ at 114 . However, the court refused to allow the suspension of the registration ruling to stand, claiming that such a suspension would serve no reasonable purpose and that the cease and desist order plus the publicity surrounding the case were punishment enough. Id. at 115 . This is the only case in which we see a limitation on allowing the agency to determine and implement its enforcement policy.

In Hanly v. Kleindienst, 471 F.2d 823 (2d Cir. 1972), cert. denied, 412 U.S. 908 (1973), the court addressed the situation in which there was an agency requirement under the National Environmental Policy Act, 42 U.S.C. $\S \S 4321-4370$ (1982), to determine the impact of a proposed agency action on 


\section{Moog and its progeny support the proposition that enforcement agencies}

the surrounding environment. Moog was cited in dictum for its language concerning agency expertise and congressional intention. Hanly, 471 F.2d at 829. The court reiterated the standard established in NLRB v. Hearst Publications, 322 U.S. 111,131 (1944), for review of mixed questions of fact and law. That standard established a "rational basis" test whereby the agency's decision will be accepted "where it has 'warrant in the record' and a 'reasonable basis in law.' " Hanly, 471 F.2d at 829 (citing Hearst, 322 U.S. at 131). Yet, the court interestingly enough opted for the less stringent "arbitrary and capricious" standard as embodied in the Administrative Procedure Act, 5 U.S.C. $\S \S$ $551-559$ (1982), thus giving even stronger support for the principle of agency discretion established in Moog. Hanly, 471 F.2d at 829.

In Sirbo Holdings, Inc. v. Commissioner, 476 F.2d 981 (2d Cir. 1973), the court of appeals addressed the question whether the payment of $\$ 125,000$ by a tenant to a landlord to restore the premises to their pre-lease condition would be considered an involuntary conversion of the landlord's property for tax purposes. In asking the lower court to reconsider the effect of the precedent, the court of appeals argued that the Commissioner could not rule one way in one case and the other way in a case with the identical facts. The court relied on the Moog Industries holding that rulings of an agency "should not be overturned in the absence of a patent abuse of discretion." Sirbo, 476 F.2d at 987 (citing Moog, 355 U.S. at 414). Finding that the inconsistent determinations in the nearly identical cases were not permissible, the court remanded the case. This, of course, shows a limitation on enforcement policy, specifically, that enforcement policy cannot violate equal protection provisions.

In Ger-Ro-Mar Inc. v. FTC, 518 F.2d 33 (2d Cir. 1975), an underwear manufacturer sought review of a cease and desist order that did not also name its competitiors. Moog was cited for the proposition that the FTC need not move against all violators. Ger-Ro-Mar, 518 F.2d at 35.

In Cross v. Board of Supervisors, 326 F. Supp. 634 (N.D. Cal. 1968), aff'd, 442 F.2d 362 (9th Cir. 1971), plaintiff sought to base a private federal civil rights complaint on, among other allegations, violations of the FTC Act, 15 U.S.C. $\S \S 41-58$ (1982). A motion to dismiss for failure to state a claim on which relief can be granted was upheld. The court found that the FTC was better equipped to prosecute these violations and cited Moog for its dictum that the FTC was the best judge and the only legal judge to develop and shape its enforcement policy. Cross, 326 F. Supp. at 637-38 (citing Moog, 355 U.S. at 413). In Winn-Dixie Stores, Inc. v. FTC, 377 F. Supp. 773 (M.D. Fla. 1974), the district court found that a cease and desist order, which the FTC refused to modify, was less restrictive against a competitor's grocery chain. Moog was cited for the proposition that similarily situated firms are not necessarily entitled to competitively equal treatment by the FTC. Winn-Dixie, 377 F. Supp. at 782. The court, however, appeared to reject that proposition in Winn-Dixie because of the presence of a favored nation trading clause in the consent decree. Id. at 783-84.

Further, courts have recognized that an agency must have freedom to develop its own enforcement policy. The need for broad agency authority was also discussed in the context of the discretion of the Commissioners of the FTC in Beltone Electronics Corp. v. FTC, 402 F. Supp. 590 (N.D. Ill. 1975). In that case, the FTC ordered affirmative disclosures of negative aspects of plaintiff's product, the absence of which, according to the FTC, made the plaintiff's advertising misleading. The plaintiff claimed the omissions were industry-wide and that the agency's ruling was unlawful. Moog was cited for its holding that whether an agency moves against only one firm or an entire industry is a matter purely within the discretion of the agency. Beltone, 402 F. Supp. at 598. Johnson Prods. Co. v. FTC, 549 F.2d 35 ( 7 th Cir. 1977), is another of the cases in which the courts have recognized that the FTC has the discretion to enforce an order against one firm that is engaged in an industry-wide illegal trade practice without simultaneously proceeding against all firms in the industry, and that the FTC's discretionary determinations may be overturned only for a patent abuse of discretion. Id. at 41 .

At the federal level there continues to be recognition of the broad authority of an agency to set up its own enforcement policy. In the case of Pendleton v. Transportation Union Sys. Corp., $430 \mathrm{~F}$. Supp. 95 (E.D. Pa. 1977), the plaintiffs filed a class action claiming violations of the Consumer Credit Protection Act, 15 U.S.C. $\$ \S 1601-1693$ (1982), by a lender and joined the FTC to compel enforcement of the provisions of the Act. Plaintiffs sought a writ of mandamus against the FTC. The court first found that the Act did not create a clear duty on the part of the FTC that could be the proper subject of a mandamus proceeding. Specifically, the statute only gave the FTC the power to enforce its provisions and did not create a duty to do so. The court treated the powers of enforcement as being broadly discretionary and relied upon Moog for the proposition that the FTC alone is empowered to determine its enforcement policy, including discretion to allocate its funds and personnel as it sees fit. Pendleton, 430 F. Supp. at 97. This idea of deference to administrative agencies is summed up in a statement by the court: "Because enforcement is essentially discretionary, courts repeatedly 
are expected to develop enforcement policy. The most important question is whether the agency abuses delegated discretion. Justice Brennan crystallized this concern in his dissenting opinion in McGautha $v$. Califormia. ${ }^{168}$ Brennan asserted that the focus of Congress has been "much less upon the definition of precise statutory standards than on the creation of other means adequate to assure that policy is set in accordance with congressional desires and that individuals are treated according to uniform principles rather than administrative whim."169 The issue, therefore, is not whether agencies should be delegated the power to make rules, but rather whether agency-developed rules are consistent with legislative policy and are uniformly applied. ${ }^{170}$

The U.S. Supreme Court decisions are clear regarding the permissibility of delegating rulemaking power to administrative agencies. The discretion needed to develop law enforcement policies would seem to fall within the range of powers properly exercised by agencies on the federal level. However, as Professor Allen points out, "our concern is with delegation in the states."171 It is his judgment that the delegation doctrine "has not been accorded the broad general approval in the states that it has received in the federal system." 172 Therefore, it is necessary to examine the development of the delegation doctrine at the state level, to determine whether the judicial approach toward rulemaking is sufficiently different at that level to preclude the development of law enforcement policy.

have refused to require prosecutors or agencies to investigate particular alleged violations or institute proceedings against certain persons." $I d$. at 97 (quoting Inmates of Attica Correctional Facility v. Rockefeller, 477 F.2d 375 (2d Cir. 1973)).

The U.S. Supreme Court and the federal courts of appeals have continued to hold, consistent with $\mathrm{Moog}$, that administrative officials possess wide discretion in formulating enforcement policy. See, e.g., Marshall v. Jerrico, Inc., 446 U.S. 238, 248-49 (1980); Encyclopedia Britannica, Inc. v. FTC, 605 F.2d 964, 973-74 (7th Cir. 1979); Noell v. Bensinger, 586 F.2d 554, 558 (5th Cir. 1978); United States v. Leggett \& Platt, Inc., 542 F.2d 655, 658 (6th Cir. 1976).

168. 402 U.S. $183(1971)$

169. Id. at 275 (Brennan, J., dissenting).

170. According to Justice Brennan, in attempting to determine the propriety of delegation of rulemaking authority, the issue is not whether an intelligible legislative policy was or was not correctly inferred from the statute: "[T]he point is that such a policy, once expressly articulated, not only serves to guide subsequent administrative and judicial action but also provides a basis upon which the legislature may determine whether power is being exercised in accordance with its will." Id. at 277-78 (emphasis added). The concern expressed by Justice Brennan over the uniformity and fairness of administrative rulemaking procedures is evident in cases such as Morton v. Ruiz, 415 U.S. 199 (1974).

These cases strongly support the argument that administrative agencies are expected to develop expertise in their fields, and, absent a clear abuse of discretion, such expertise is to be deferred to by the courts. As stated in Morton, the power of a federal administrative agency "necessarily requires the formulation of policy and the making of rules to fill any gap left, implicitly or explicitly, by Congress." 415 U.S. at 231.

171. Allen, supra note 2 , at 87.

172. Id. 


\section{B. State Delegation}

Professor Allen argues that the scope of delegation of power is substantially different at the state level. ${ }^{173} \mathrm{He}$ begins his discussion of state delegation by referring to Howell $v$. State, ${ }^{174}$ a case which "does not state the majority position in the United States [although] there is significant support for [its] 'old-fashioned' view." 75 In Howell, the Mississippi Supreme Court reviewed a Uniform Controlled Substances Act ${ }^{176}$ passed by the state legislature. The Act classified controlled substances into five schedules but gave power to the State Board of Health to add, delete, or reschedule any substances subject to specific guidelines provided in the statute. The Board rescheduled amphetamines from schedule III to schedule II, and the effect of the change was to increase the minimum penalty for possession of amphetamines from one to two years. A defendant who was convicted of unlawful possession of amphetamines and sentenced to two years in prison argued on appeal that the statute which authorized the Board to reschedule controlled substances was an unconstitutional delegation of power. The Mississippi Supreme Court agreed with the defendant and held "that the authority to define crimes and fix the punishment therefor is vested exclusively in the legislature, and it may not delegate that power either expressly or by implication . . . ."177

Professor Allen indicates that Howell is an important case; however, there is considerable difficulty in analogizing it to law enforcement policymaking. Howell is a case involving a type of rulemaking which is not at issue in developing law enforcement rules. The goal in developing law enforcement rules is not to criminalize conduct which presently is not criminal, nor is it to increase the penalities provided by criminal statutes, as was the case in Howell. In developing rules to control police arrest decisions, the goal is to ensure uniform and fair application of the criminal law, to ensure that police conduct in law enforcement is not arbitrary and capricious. The goal of criminal law enforcement policymaking is not to abrogate or add to the penalties set by the legislature but rather to define more accurately the circumstances in which the law can realistically be enforced, and to enforce all laws when it is possible to do so in the manner in which the legislature expected such laws to be enforced.

Howell presents the situation in which the State Board of Health action did result in an increase in penalty. Furthermore, the action of the Board was essentially the equivalent of reclassification of a crime from a misdemeanor to a felony. ${ }^{178}$ While the court in Howell did not address the upgrading of the crime, the point is by no means inconsequential. Felonies are major crimes to

173. Id.

174. 300 So. 2d 774 (Miss. 1974).

175. Allen, supra note 2, at 90 (quoting Schwenk, The Administrative Crime, Its Creation and Punishment by Administrative Agencies, 42 MICH. L. REV. 51,61 (1943) (footnote omitted)).

176. Miss. Code ANN. \$\$ 41-29-101 to-183 (1972).

177. Howell, 300 So. 2d at 781 (Miss. 1974).

178. H. Packer, The limits of the Criminal Sanction 142 (1968). 
which, as compared with misdemeanors, society attaches much greater significance, both morally and legally. ${ }^{179}$ Courts are likely to scrutinize more closely crimes that are classified (or reclassified) as felonies than those classified as misdemeanors. When agency action results in an increase in penalty for a violation, the question whether the agency has invaded the province of the legislature takes on much greater significance. Increasing penalties squarely raises the question whether there has been an inappropriate tampering with the explicit policy decisions of the legislature.

There are additional points of departure between police rulemaking and reclassification of crimes. From the standpoint of the individual (potential defendant) there is a practical difference. In cases similar to Howell a defendant can complain that the administrative agency, not the legislature, has in essence "upped the ante," but absent clear violations of equal protection or due process provisions, ${ }^{180}$ that same person cannot complain about decisions which result in underenforcement of the law.

There are also differences from an institutional standpoint. There is an inherent qualitative distinction between an administrator's changing a statute by increasing penalties for crimes and his determining the circumstances under which the legislature expects a statute to be enforced. The expectation of discretion in choosing an enforcement policy is also supported by a "necessity" argument which recognizes the practical problems faced in law enforcement decisionmaking. By contrast, one might argue the exercise of discretion in Howell was not essential to the proper performance of any governmental activity.

Only the legislature can define crimes. At the same time governmental agencies and even the general public have an amplifying role to play in deciding the impact of the criminal laws. The role of the general public is seen in the expectation that grand juries are to serve as a shield against abuses of prosecutorial discretion, ${ }^{181}$ and that petit juries can nullify the effect of the criminal law in some circumstances. ${ }^{182}$ What happened in Howell is quite different from this normal amplifying function.

The goal of criminal law enforcement policymaking is to set standards to determine fairly and equitably within statutory limits ${ }^{183}$ when violators should be arrested. There is a substantial difference between this goal and what was done in Howell; law enforcement policymaking, as contrasted with "rescheduling" controlled substances, does not increase the severity of crimes nor does it have any effect on the ability of the courts to assess penalties as specifically provided for by the state legislatures.

The closest that Howell comes to the real crux of criminal law enforcement policymaking is to suggest a situation in which an agency might reschedule

179. Id. at 139-145.

180. See infra notes $267-315$ and accompanying text.

181. United States v. Cox, 342 F.2d 167, 170 (5th Cir.), cert. denied, 381 U.S. 935 (1965).

182. United States v. Dougherty, 473 F.2d 1113,1136 (D.C. Cir. 1972).

183. See Howell, 300 So. $2 \mathrm{~d}$ at 781 . 
controlled substances downward, reducing the penalty and in essence overriding the original legislative directive. Such an analogy seems to be false because, again, the proper focus of law enforcement policymaking is to determine the circumstances in which laws should be enforced according to the intention of the legislature; such policymaking should have no impact on the penalties imposed upon those ultimately found guilty of violating criminal statutes.

Even if a parallel does in fact exist between Howell and law enforcement policymaking, there remains the important question whether "there is significant support for Howell's 'old-fashioned view." "184 Since the Howell decision, the clear consensus of both federal and state courts that have addressed the issue of whether a legislature may delegate to an agency the power to reschedule controlled substances has been that such delegation is permissible. ${ }^{185}$ In fact many courts have permitted administrative agencies much broader powers than are necessary to validate police rulemaking. ${ }^{186}$ The significance of Howell, therefore, must be questioned.

As Professor Allen admits, Howell does not express the majority position of the states on the delegation question. ${ }^{187}$ A substantial number of state courts have determined that legislatures may delegate some power to administrative agencies to promulgate rules concerning the substantive criminal law. ${ }^{188}$ However, Professor Allen's research has led him to conclude that such criminal law rulemaking has been permitted only in very narrow circumstances. According to Allen, it is permitted only when the subject matter requires particular skills or expertise that could not be demanded of the legislature ${ }^{189}$ or when the development of rules would require the legislatures "to spend vast amounts of time on relatively inconsequential matters." 190 He concludes that developing criminal law enforcement policy would fall into neither category and thus would not be permitted. ${ }^{191}$

This conclusion cannot withstand close scrutiny. First, it is based on the assumption that law enforcement work does not require special skills or technical expertise. That assumption is questionable in light of the myriad duties modern police are called upon to perform, and the highly specialized training

184. See supra note 175 and accompanying text.

185. People v. Avery, 67 III. 2d 182, 367 N.E.2d 79 (1977), is illustrative of the proposition that delegation of power to reschedule controlled substances is considered an acceptable delegation of power at the state level. See also State v. Davis, 450 S.W.2d 168, 170 (Mo. 1970); People v. Uriel, 76 Mich. App. 102, 255 N.W.2d 788 (1977); federal cases cited infra note 188.

186. See infra notes $256-65$ and accompanying text.

187. Allen, supra note 2 , at 90.

188. People v. Uriel, 76 Mich. App. 102, 255 N.W.2d 788 (1977); State v. Davis, 450 S.W.2d 168 (Mo. 1970). Contra In re Powell, 92 Wash. 2d 882, 602 P.2d 711 (1979); State v. Gallion, 572 P.2d 683 (Utah 1977). For federal cases which also support this point, see United States v. Gordon, 580 F.2d 827 (5th Cir. 1978), cert. denied, 439 U.S. 1051 (1978), cert. denied, 439 U. S. 1079 (1979); United States v. Pastor, 419 F. Supp. 1318 (S.D.N.Y. 1975).

189. Allen, supra note 2 , at 92.

190. Id. at 94 .

191. Id. at 95. 
they receive in most states. ${ }^{192}$ In fact, one might argue that legislatures have explicitly recognized the technical nature of modern police work by the types of tasks they have assigned to the police and by requiring that law enforcement officers receive specialized training before they undertake those tasks. Recently, nationwide, there has been a significant increase in legislatively mandated training for law enforcement officers. For example, in Iowa there is an attempt to provide not only skills training but also training in sociology, psychology, and criminal law to aid officers in resolving the problems encountered in their work. ${ }^{193}$ Legislatively mandated police training of this character clearly indicates an awareness that law enforcement requires considerable expertise and the ability regularly to exercise broad discretion in decisionmaking.

Even Professor Allen implicitly admits that police officials are expected to make law enforcement policy: how else would they engage in the resource allocation decisions he condones? ${ }^{194}$ Actually, decisions as to the allocation of personnel ${ }^{195}$ involve the thoughtful and knowledgeable reflection of community goals, police capabilities, and the criminal law. The ability to engage in these activities requires a highly sophisticated analysis of political, legal, and social factors. This process may not involve the exceedingly complex analysis required in some other administrative areas-in determining the danger of pesticides, for example; yet it requires more than rigid adherence to the specific language of criminal statutes.

Unfortunately, Professor Allen does not fully develop what he regards as the second exception to the general prohibition against rulemaking: that legislatures will permit rulemaking rather than spend vast amounts of time on relatively minor matters. He merely says it is not applicable to police work. ${ }^{196}$

192. Training of police personnel is a relatively new phenomenon. The importance of training to upgrade the abilities of the police officer was not recognized until World War II. PUBLIC ADMINIStrative Service, Police and Fire Services of the City of Meriden, Conn. 110 (1962). It seems the primary reason for the slow development of training for police officers was the general resistance from within the police departments. This resistance was also reflected in the prevailing public opinion that training of officers was superfluous since a police officer best learned his job by performing it.

The Wickersham Report of 1931 stated that of 383 cities, only about $20 \%$ conducted any training of their police officers and in smaller cities (those with fewer than 10,000 people) there was not even a pretense of training. National Commission on Law Observation and Enforcement, Rep. No. 14, RePort on Police 70-71 (1931). Most of the training that was given was of the military type, which included instruction on military drills, firearms, U.S. Army calisthenics, first aid, etc. Considerable change has been made in the extent of police training since the Wickersham Report. A 1965 survey conducted by the International City Managers' Association showed that of 1352 cities, 1136 conducted some form of training for their officers. 33 International City Managers' Ass'n, Municipal YEARBOOK, 1966, at 435. The amount of initial training varies extensively, from less than one week in some cities, to nine months in the case of the Chicago Police Department. One report recommends 400-600 hours of classroom work; these recommendations are being met with increasing frequency. See U.S. Task Force on the Police, Task Force Report: The Police (1967).

193. Officers at the Iowa Law Enforcement Academy are also required to take at least two courses which focus on the exercise of discretion by the police. Interview with John Callaghan, Director of the Iowa Law Enforcement Academy, Camp Dodge, Iowa (March 1980).

194. Allen, supra note 2 , at 113.

195. Id.

196. Id. at 95 . 
A closer look is required. Felonies can certainly be classified as matters which deserve close legislative attention, whereas minor or "low visibility" crimes arguably present a different situation. In creating two major categories of crimes, felonies and misdemeanors, state legislators have recognized that there are different levels of concern with criminal conduct; that some violations of the criminal law have a greater societal significance than others, and thus, the enforcement of some crimes deserves more attention than the enforcement of others. Most major crimes, namely felonies, present the "strongest force that we permit official agencies to bring to bear on individuals;" 197 but it is doubtful that minor crimes such as public intoxication and simple assault have the same degree of importance to society. ${ }^{198}$

It is important, however, that enforcement strategies for minor criminal violations be developed. While such crimes are "inconsequential," in the sense that violations are less likely than felonies to have a significant impact on the basic moral structure of society, it is important to monitor such minor violations for at least two reasons. First, minor crimes require a substantial amount of law enforcement officers' time. It has been documented that more than one-half of the time officers spend enforcing the law is spent on these minor or low visibility crimes. ${ }^{199}$ Second, these crimes constitute such a large part of policy because lack of uniformity, perceived as such by the public, undermines crucial public support for law enforcement agencies. ${ }^{200}$

The conclusion one must draw with regard to minor crimes is that the legislature has criminalized such conduct, but the "emphatic denunciation"201 of the community is absent. These minor crimes are designed primarily as "order maintenance" crimes. ${ }^{202}$ They are not expected to be fully enforced, but to be enforced when their violation conflicts with the general goal of maintaining order. Enforcement of low visibility crimes requires an interpretation by the police of what the legislatures intended for the police to do. Clearly the legislature does not have the time to articulate fully the situations

197. Id. at 95 n.144 (citing Wechsler, The Challenge of a Model Penal Code, 65 HARv. L. Rev. 1097, 1098 (1952)).

198. The different levels of penalties provided for misdemeanors and felonies convey, according to the general view, the priorities established by the state legislatures; these distinctions should be reflected in law enforcement policy. Felonies are clearly more important and should receive a higher enforcement priority. To get a better grasp on the felony-misdemeanor dichotomy, it is beneficial to look at the distinction between malum prohibitum and malum in se. Malum prohibitum crimes are frequently misdemeanors because, even though they do not violate significant moral principles of society, legislative bodies have determined that such crimes are socially disruptive and must be regulated. Black's Law Dictionary 865 (5th ed. 1979); see State v. Shedoudy, 45 N.M. 516, 525, 118 P.2d 280, 286-87 (1941); People v. Pavlic, 227 Mich. 562, 565-66, 199 N.W. 373, 374 (1924). Thus, while crimes like disorderly conduct, public intoxication, gambling, and simple assault are not as great a threat to personal security as are crimes like murder, armed robbery, kidnapping, and burglary, they are nevertheless outlawed in the interest of social stability. In establishing priorities, it would certainly seem more appropriate for legislatures to spend the time they have available on matters connected with malum in se crimes rather than malum prohibitum crimes.

199. K. Davis, supra note 1 , at 64 .

200. See id. at $112-20$.

201. See Allen, supra note 2, at 92 n.138.

202. J. Wilson, Varieties of Police Behavior 16-18 (1968). 
in which laws against low visibility offenses or minor crimes should be enforced; legislatures would generally prefer not to have to spend vast amounts of time detailing when a person should be arrested for public intoxication, or whether an arrest for assault should be made in every case in which a person is slapped. The police are expected to keep order and those minor offenses are designed to aid the police in that job.

Professor Allen's error is that, while he recognizes that some governmental matters-such as the tasks of overseeing sewers and running airports-can be delegated to an agency, he fails to see that similar parts of criminal justice administration are likewise delegable. ${ }^{203}$ If one closely scrutinizes the criminal laws, one finds that "low visibility" crimes are closer to the so-called "trivial and mundane" acts, which he recognizes as appropriately regulated through delegated power, ${ }^{204}$ than to major crimes. For example, it is very doubtful that a person arrested for public intoxication would be viewed as more of a criminal than Professor Allen's example of one who "disposes of his garbage improperly or fails to close his bar on time."205 The administrative or regulatory crimes distinguished by Professor Allen are very much akin to low visibility crimes, in which the "emphatic denunciation" of the community is absent. ${ }^{206}$ As Professor Allen says, "there is more to the criminalization process than mere labeling" 207 and, by looking beyond the labels, one discovers a class of crimes which meets the requirements he outlines for a constitutionally permissible delegation of power. ${ }^{208}$

\section{Delegation in Iowa}

The thrust of Howell $v$. State ${ }^{209}$ is limited and arguably means only that a state legislature cannot delegate power to a state agency to reclassify drugs if such reclassification would result in an increase in penalty. While Professor Allen points out that Howell is not illustrative of the approach most states take toward the question of delegation, he does cite cases from six states as significant support for the proposition established by Howell. ${ }^{210}$

Professor Allen concedes that there are some states that do not fit within his model. ${ }^{211}$ It therefore seems appropriate, in light of the unsettled nature of state law on this subject, to review the development of the law in one of the states which admittedly does not fit Professor Allen's thesis.

One state he characterizes as not fitting within his model is Iowa. ${ }^{212}$ When one looks at the development of the delegation doctrine in Iowa one finds, as

203. See Allen, supra note 2, at 94-96.

204. Id. at 94 .

205. See id. at 92 n.138.

206. See id.

207. Id. at $92-93$ n. 138 .

208. Id.

209. 300 So. 2d 774 (Miss. 1974); see supra notes 174-86 and accompanying text.

210. Allen, supra note 2, at 90 n.126.

211. The states are South Carolina and Iowa. See Allen, supra note 2, at 96 n.150.

212. Id. 
expected, that a strong case can be made that a statute authorizing law enforcement policymaking would be constitutionally permissible. Analysis of Iowa case law indicates that the Iowa Supreme Court's position on delegation has evolved through at least four stages, tending to become more expansive in permitting the delegation of power to administrative agencies. ${ }^{213}$ The first stage is commonly characterized as the "findings-of-fact" period."214 The approach during this period is exemplified by two Iowa cases: Hubbell v. Higgins $^{215}$ and Goodlove v. Logan. ${ }^{216}$ In Hubbell, the Iowa Supreme Court upheld a statute authorizing a hotel inspector to use his discretion to determine whether hotels had "approved fireproof construction" and particular "approved sanitary conditions." 217 According to the court, the delegation of this power was permissible because the law did not permit the inspector to act arbitrarily, but rather authorized him to find whether the facts warranted application of the statute. ${ }^{218}$ In Hubbell, there was an implicit understanding that some decisions concerning whether a law has been violated will of necessity be vested in an administrator; but those decisions must be limited.

The importance of placing limits on discretionary powers of administrators was reinforced in Goodlove. In that case the Iowa Supreme Court invalidated a statute permitting the State Highway Commission to promulgate rules for highway safety. Under the statute, the Highway Commission had enacted a rule which made it illegal to stop a car upon a paved highway except in particular circumstances. ${ }^{219}$ The court held that the legislature had exceeded its authority by delegating power to the Highway Commission to enact rules and regulations concerning the use of highways because any statute that delegates to an agency the power to determine first, " whether there shall be any law, and, second, what the law shall be," is a delegation of legislative power and is unconstitutional. ${ }^{220}$ Neither Hubbell, Goodlove, nor any other case during that period defined the boundaries of the powers that could properly be delegated.

213. Note, supra note 136 , at 976 .

214. Id. at 976 n.20 (quoting K. DAvis, supra note $128, \S 2.01$, at 26-27).

215. 148 Iowa 36,126 N.W. 914 (1910).

216. 217 Iowa 98,251 N.W. 39 (1933).

217. Hubbell, 148 Iowa at 43-45, 126 N.W. at 917. The Act of Mar. 27, 1909, ch. 168, § 6, 1909 Iowa Acts 162, 168 provided: "[A]ll hotels shall be kept and maintained in a clean and sanitary condition and free from [any] efluvia, gas or offensive odors arising from any sewer, drain, privy, or any other source whatever within the control of the owner, manager, agent or person in charge thereof."

218. Hubbell, 148 Iowa at 43-45, 126 N.W. at 917.

219. Goodlove, 217 Iowa at 99,251 N.W. at 40.

220. Id. at 108,251 N.W. at 43. To support his position that, in states where delegation of rulemaking authority has been upheld, it has been limited to "subject matters [which] required particular skills or attributes that could not reasonably be demanded of a legislature," Professor Allen cites 18 cases from 14 states. Allen, supra note 2, at 91-94. If one assumes that Professor Allen is accurate in his assessment of the position of the states, six states clearly prohibit the delegation of rulemaking authority to agencies, and 14 permit such delegation in narrowly prescribed circumstances. As suggested by Professor Allen, at most only 22 state courts had addressed the issue raised in Howell. This leaves 28 states with no settled law on the issue of whether the state legislature may delegate crime-defining power to an administrative agency. 
The second, or "filling-up-the-details," period was a step in that direction. ${ }^{221}$ The Iowa Supreme Court began to concentrate on the distinctions between legislative power and a "subsidiary power to fill up the details" of a general statute to effectuate legislative policy. The second period is exemplified by the case of State $v$. Manning. ${ }^{222}$ In Manning, the Iowa Supreme Court reviewed the power granted to the state budget director to approve all money transfers sought by municipal officers. The allegation was made that the State Budget Act was an unconstitutional delegation of power because it set up "no standard of conduct to guide the budget director in . . . making his decision with reference to transfer of funds . . ."223 The court held, however, that the Act was valid because it was permissible for the legislature to delegate to an agency "the working out of the details of carrying out and administering the will of the Legislature [as] expressed by the statute." 224 This broad range of delegation was held to be permissible because the legislature was compelled to discover new means of delegation due to the increasing "complexities of business, governmental and economic existence."225

There was some concern over the wide range of choice permitted under the "filling-up-the-details" approach, and courts soon began looking for guidelines in statutes which delegated power to administrative agencies. In most cases the search was for express standards to guide administrators in the performance of their jobs. ${ }^{226}$ The Iowa Supreme Court expressed some concern about "standards" in Manning 227 but it was not until State v. Van Trump 228 that this concern became predominant.

Van Trump signals the beginning of the "standards" stage. In Van Trump, the court analyzed "the nature of the authority" 229 delegated under a statute which authorized the Iowa Conservative Commission to adopt rules and regulations "for the proper use and conservation of the resources of [Iowa]. ${ }^{230}$ Violations of the Commission's rules and regulations were to be penalized as misdemeanors. ${ }^{231}$ Finding "no sufficient 'yardstick' or statement of legislative policy in the broad grant of power to the conservation commission," 232 the court held that the rules were without authority and void. ${ }^{233}$

It must be noted, however, that while the Van Trump court would not

221. Note, supra note 136, at 980 (quoting K. DAvis, supra note 128, § 2.01, at 26-27).

222. 220 Iowa 525, 259 N.W. 213 (1935).

223. Id. at 529, 259 N.W. at 216.

224. Id. at 532, 259 N.W. at 217.

225. Id.

226. Note, supra note 136 , at 982 .

227. While the court found that it was necessary "to vest unguided discretion in supervising and directing the disposition and transfer of funds," Manning, 220 lowa at 534, 259 N.W. at 218, the court also found that "the Budget Act, properly interpreted, contains ample provision for guidance and direction of the budget director in making his decisions." Id. at 535-36, 259 N.W. at 219.

228. 224 Iowa 504, 275 N.W. 569 (1937).

229. Id. at 507,275 N.W. at 571 .

230. Id. at 509,275 N.W. at 572 .

231. Id. at 504-05, 275 N.W. at 570 .

232. Id. at 509, 275 N.W. at 572 .

233. Id. 
permit the delegation of "strictly and exclusively legislative" duties, ${ }^{234}$ it did not narrow the scope of delegation held permissible in Manning. Rather, the court stated that

$[N]$ government, embodying the principles of the separation of power could function if the legislature were prohibited from conferring power or authority of any character upon executive or administrative officials.

When the legislature lays down an intelligible and complete declaration of policy which is definite in describing the subject to which it relates or to the field wherein it shall apply, and the character of regulation which is intended to be imposed, it is proper to leave to a nonlegislative body the manner in which that general policy shall apply to varying situations. ${ }^{235}$

Thus, the Iowa Supreme Court, while requiring that the legislature establish a clear general policy, recognized that the nature of democratic government left the three branches with overlapping functions. The concern of the court was not over delegation qua delegation, but that the power of the administrative agency be carefully circumscribed. According to Van Trump, delegation was permissible if, and only if, the potential for arbitrary and capricious administrative action was legislatively eliminated.

The Iowa Supreme Court quickly retreated from the rigid position developed in Van Trump and began to follow much more literally the approach taken in Manning, which recognized that increasing government complexities demanded the delegation of powers to administrative agencies. The court, about thirty-five years after Van Trump, expanded the presumption of validity of legislative delegation of authority and found quite general legislative directives to be constitutionally valid standards. ${ }^{236}$ The adoption of the "standards" approach by the supreme court did not dispel all the concerns about keeping the power of agencies within bounds. The Iowa Supreme Court, like other courts, continued to stress the need for standards, but generally tended to invalidate delegation of power only if there was a lack of "safeguards" to protect the rights of those within the ambit of agency control. Moreover, when a court finds inadequate safeguards, the general trend has been to hold that agency action was ultra vires rather than the exercise of an unconstitutionally delegated power. ${ }^{237}$ This approach saves the statute from being invalid while giving the court power to monitor the actions of the administrative agency.

This trend was reinforced in Warren County $v$. Judges of the Fifth Judicial District. ${ }^{238}$ In Warren County, the Iowa Supreme Court upheld a statute which delegated to the chief judge of each judicial district having three or more parttime magistrates authority to order the substitution of a full-time magistrate for the incumbent part-time magistrates of a county, provided a majority of the judges of the judicial district had voted in favor of the substitution. ${ }^{239}$

234. Id. at 507,275 N.W. at 571 .

235. Id. at 507-08, 275 N.W. at 571 .

236. Grant v. Fritz, 201 N.W.2d 188, 193 (Iowa 1972).

237. Interview with Professor Arthur Bonfield, in Iowa City, Iowa (October 4, 1980).

238. 243 N.W.2d 894 (Iowa 1976).

239. Id. at $900-01$ 
The court articulated the following factors that would be considered in determining the validity of delegation of authority: (1) whether public interest is best served by the delegation; ${ }^{240}$ (2) whether it is impossible for the legislature to function in the area delegated to an agency; ${ }^{241}$ and (3) whether, in lieu of standards, adequate safeguards are institutionalized to protect those affected by the agency's action. ${ }^{242}$ The court found that the statute challenged in Warren County allowed the chief judge to use his particular expertise, while "in fact limit[ing] the scope of the judges' authority as much as practicalities allow." 243

Warren County indicates that the Iowa Supreme Court continues to strive for "a 'common sense' policy in determining the extent to which delegation may be permitted," 244 remaining aware of the need to recognize the increasing complexities of modern democratic government. The court stated: "[W]e look to the practical necessities of public interest and will consider as an important factor the difficulty or impossibility of calling for the legislature to function in a given area." 245

The approach of the court in Warren County, in establishing factors to determine acceptable rulemaking, is similar to the approach developed by Professor Allen. ${ }^{246}$ However, the two seem likely to diverge in their conclusions. In analyzing a statute delegating rulemaking power to the police, the Iowa Supreme Court would probably, under Warren County, first ask whether the public interest is best served by the delegation of authority. Professor Allen would probably argue that it is not, but it appears that the Iowa court might disagree with him. This, of course, is a public policy judgment. The courts are likely to leave it to the legislatures and to assume that the question is largely answered by the passage of legislation authorizing police rulemaking.

The second of the Warren County factors, whether it is impossible for the legislature to function in the area delegated to an agency, would seem to be analogous to cases decided by the Iowa Supreme Court which have recognized the "practical necessities of public interest" in vesting broad discretion in agencies concerned with public safety. In State $v$. Rivera, ${ }^{247}$ the court upheld a statute against claims of unconstitutional delegation on the grounds that there was an enhanced need for administrative discretion in situations

240. Id. at 899 (citing Spurbeck v. Statton, 252 Iowa 279, 290, 106 N.W.2d 660, 666 (1960)); see also Danner v. Hass, 257 Iowa 654, 134 N.W.2d 534, 540 (1965) (overruled in Needles v. Kelley, 261 Iowa 815,156 N.W.2d $276(1968)$ ).

241. Warren County, 243 N.W.2d at 899-900 (citing State v. Rivera, 260 lowa 320, 325, 149 N.W.2d 127, 131 (1967)).

242. Warren County, 243 N.W.2d at 900 (citing Iron Workers Local No. 67 v. Hart, 191 N.W.2d 758, 772 (Iowa 1971)); see also Elk Run Tel. Co. v. General Tel. Co., 160 N.W.2d 311, 317 (Iowa 1968).

243. Warren County, 243 N.W.2d at 901 (emphasis added).

244. State v. Van Trump, 224 Iowa 504, 506, 275 N.W. 569, 570 (1937)

245. Warren County, 243 N.W.2d at 900.

246. See supra notes $\mathbf{1 8 9 - 9 0}$ and accompanying text.

247. 260 Iowa 320,149 N.W.2d 127 (1967) 
involving public safety. ${ }^{248}$ Similarily, the Iowa case of Spurbeck $v$. Statton ${ }^{249}$ recognized the exceptional need for administrative discretion in the area of public safety. ${ }^{250}$

Though Rivera dealt with the "safe and sane regulation of . . . motor vehicle transportation," 251 it is instructive in connection with police rulemaking because of its explicit recognition that the legislature is not the sole repository of expertise about public safety issues. ${ }^{252}$ This attitude of the Iowa Supreme Court is likely to lead to a second ground for disagreement between the Iowa courts and Professor Allen. ${ }^{253}$

The third concern of Warren County, that adequate safeguards be institutionalized to ensure that the action of the agency is fair and impartial, ${ }^{254}$ is more difficult to analyze in the selective enforcement context. Because we have no history of formal rule development by the police, and because informal rules that are presently in existence are not susceptible to analysis, it is difficult to gauge whether present enforcement is impartial. ${ }^{255}$ However,

248. The court in Rivera stated: "The legislature recognized, as we do, that statutes cannot always detail motor vehicle safety regulations under all highway conditions. It therefore has, in certain areas, given the State Highway Commission authority to carry out the purposes of its statutes." Id. at 325,149 N.W.2d at 131 .

Earlier courts have recognized the same proposition:

It is manifest that the legislature, in seeking to control . . . businesses subject to its control . . cannot always anticipate and foresee all the conditions that may arise affecting the conduct of the business. . . . It, therefore, may delegate to the ministerial officers certain powers, somewhat judicial in their nature, the exercise of which is essential to the proper and effectual carrying out of the purpose and object of the law itself . . .

Danner v. Haas, 257 Iowa 654, 663, 134 N.W.2d 534, 540 (1965) (citing Noble v. English, 183 Iowa $893,895,167$ N.W. $629(1918))$.

249. 252 Iowa 279,106 N.W.2d 660 (1960).

250. Another example of the Iowa courts recognizing the need for more administrative discretion in the area of public safety is Sueppel v. Eads, 261 Iowa 923, 156 N.W.2d 115 (1968). The trial court had set aside the state department of public safety's order suspending the driver's licenses of three "habitual violators" saying that the term "habitual violator" was not defined and was too indefinite. The Supreme Court of lowa disagreed. It cited a Minnesota case, Anderson v. Commissioner of Highways, 267 Minn. 308, 126 N.W.2d 778 (1964), which upheld a statute using the term "habitual violator." The lowa court, quoting the Minnesota court, said:

[w]hile the privilege [of driving] is a valuable one, and may not be unreasonably or arbitrarily taken away, its enjoyment depends upon compliance with conditions prescribed by law and is always subject to such regulation and control as public authority may see fit to impose under the police power in the interest of public safety and welfare.

Sueppel, 261 Iowa at 928, 156 N.W.2d at 118 (quoting Anderson, 267 Minn. at 317, 126 N.W.2d at 784). The Iowa court found this rationalization applicable and persuasive in upholding the statute as not too broad. 261 Iowa at 928-29, 156 N.W.2d at 118. In Richard v. Holliday, 261 Iowa 181,153 N.W.2d 473 (1967) (overruled in Needles v. Kelley, 261 Iowa 815, 156 N.W.2d 276 (1968)), the plaintiff claimed that the department of transportation was required to have definite standards for determining what constituted a "serious violation." The supreme court followed Danner, 257 Iowa at 661-64, 134 S.W.2d at 539-41, and said "[T]he statutory language 'a serious violation", is a sufficient standard to permit the department to use its discretion and judgment." 261 Iowa at 191,153 N.W.2d at 479. Plaintiff had her license revoked.

251. 260 lowa at 325,149 N.W.2d at 131 .

252. See Rivera, 260 Iowa 320,149 N.W.2d 127.

253. See supra note 246 and accompanying text.

254. See supra note 242 and accompanying text.

255. It is generally accepted by those who have reviewed police work that the arrest decisions of officers are guided largely by informal norms. See G. Williams, Law and Politics of Police DiscreTION 4-7 (1984). 
one could make a strong case that the existence of formal rules developed under legislative authorization would substantially enhance the likelihood of institutional safeguards.

The case of State $v$. Watts ${ }^{256}$ sheds some additional light on the question of institutionalizing safeguards. In Watts, the court considered the constitutionality of a statute which provided that any violation by a parolee of the rules established by the parole board would be deemed a felony. ${ }^{257}$ The defendant, who had been found guilty of violating the rules of his parole, contended that the statute set forth an unconstitutionally broad grant of power by allowing the board to define the conduct made criminal by the statute. ${ }^{258}$ The court, however, finding that the rulemaking authority was properly delegated, held that the statute was constitutional. ${ }^{259}$ According to the court, while only the legislature has the power to create and define crimes, "[ $t$ ]he board of parole neither defines or creates a crime nor determines the punishment. The legislature itself prescribed that a violation of any rule or regulation or condition of a parole of the administrative agency granting the parole was a felony. . . . 260 The court in Watts, although finding there were no substantive guidelines in the statute sub judice, upheld that statute, which created and empowered the parole board to make rules for parolees, on the ground that the "[p]rocedure established for the exercise of the power furnishes adequate safeguards to those who are affected by the administrative action . . . ."261

The development of law enforcement rules would not need to go as far as the process that was upheld in Watts. One could argue that the parole board in Watts, by setting specific conditions of parole, was defining crimes. The police, in drafting rules to control criminal law enforcement, would neither define nor create crimes. The legislature would define the elements of the crime and establish the general policy of enforcement; the police would merely interpret the policy and formulate rules that, when effected, would ensure that the objectives of the legislature were achieved. ${ }^{262}$ While under law enforcement rules a person might not be arrested for an act or omission which technically violates a criminal statute, the rules do not expand the scope of the legislatively enacted policy. Therefore, even if the rules adopted create a lesser probability of arrest than would occur by strictly enforcing the criminal statutes, the police will be acting within their delegated authority. ${ }^{263}$ Constriction of a statute, as discussed previously, is appropriate under both an

256. 186 N.W.2d 611 (Iowa 1971).

257. Id. at 613 .

258. Id. at 615 .

259. Id. at 616 .

260. Id.

261. Id. (citing Elk Run Tel. Co. v. General Tel. Co., 160 N.W.2d 311, 317 (Iowa 1968)). 10.

262. For an example of how to approach development of specific rules, see Williams, supra note

263. In City of Des Moines v. Reiter, 251 lowa 1206, 102 N.W.2d 363 (1960), the Iowa Supreme Court noted that "[t]he fact that a [municipal] ordinance enlarges on the provisions of a statute by requiring more than the [state] statute requires creates no conflict therewith." Id. at 1209, 102 N.W.2d at 366 . The court in Reiter also held that "[u]nless restrained by statute a municipality may in 
"amplification" and a "necessity" theory, while expansion of a statute is clearly impermissible because it adds to legislative commands, either by punishing persons not intended to be punished or by punishing them in a way different from the contemplated by the legislature. ${ }^{264}$

It would not only be unlikely but ironic if the Iowa Supreme Court were to determine that the delegation of power to develop rules to control criminal law enforcement is unconstitutional. That conclusion would have the effect of stifling the development of safeguards against arbitrary administrative actsthe exact type of safeguards which the court recently has found to be so important. ${ }^{265}$

In analyzing how the delegation of power doctrine has developed in Iowa, one finds the Iowa Supreme Court using a different approach from that suggested by Professor Allen. Although the Iowa Supreme Court remains

its discretion determine for itself the method of exercising powers conferred upon it." Id. at 1212 , 102 N.W.2d at 367.

264. Another example of an approach different from that of Professor Allen's is evident in a Washington case decided in 1980. In State v. Bryan, 93 Wash. 2d 177, 606 P.2d 1228 (1980), the Supreme Court of Washington upheld a delegation to the Department of Social and Health Services to establish sentencing regulations governing juvenile offenders. The trial judge, called upon to pass sentence on a juvenile offender, felt that the application of the standards would result in very little punishment for the juvenile. The trial court judge declared the sentencing guidelines provided by the Juvenile Justice Act of 1977, WASH. Rev. CODE ANN. $\$ 1340$ (1977), and administrative regulations promulgated pursuant to it unconstitutional and committed the juvenile to the Division of Institutions.

While the Washington Supreme Court noted that the determination of crimes and punishments has traditionally been a legislative prerogative, it stated that the legislature may constitutionally delegate its power to define sentences. The court's concern was that constitutional requirements be met: primarily, that "the legislature provide standards defining generally what is to be done and what body is to accomplish it and [that] procedural safeguards be established to control arbitrary administrative action." 93 Wash. $2 \mathrm{~d}$ at 181,606 P.2d at 1230. In Bryan, the state conceded the adequacy of standards, so they were not an issue. The court stated:

RCW 13.40.030(1), (5), (6) \& (7) provide an explicit set of standards governing the period of confinement or other supervision based on the offense committed and a wide range of other listed factors. The standards are at least as complete as those considered by this court in State $v$. Mulcare, 189 Wash. 625, 66 P.2d 360 (1937), in which the indeterminate sentence act establishing the Prison and Parole Board to set sentences within legislatively-prescribed maximums was upheld. For instance, RCW 13.40 .030 (1) provides that the sentencing standards must be established "on the basis of a youth's age, the instant offense, and the history and seriousness of previous offenses, but in no case shall the period of confinement and supervision exceed that to which an adult may be subjected for the same offense(s)". The section goes on to require that standards for sentencing "serious offenders" shall not be less than thirty days, and provides explicit restrictions on the possible lengths of time and sentencing alternatives that may be proposed. RCW 13.40.030(6) \& (7) set out the permissible ranges of confinement in greater detail. Id. at 181-82, 606 P.2d at 1230-31. In addition to standards the court found that the legislature had included safeguards in the authorizing legislation. As part of the Juvenile Justice Act, the legislature "reserves the right to review, adopt, or require modification of the proposed standards. RCW 13.40 .030 (2) \& (3)." Id. at 182, 626 P.2d at 1231. The court further found that the legislature built into the statute provisions to facilitate constant monitoring of the administrative agency. Specifically, the proposed guidelines will always be before the legislature in a year in which a legislative session is mandated. WASH. Const. art. $2, \S 12$. The end result was that the supreme court found the standards adequate and the safeguards sufficient to ensure that the statutory scheme proposed did not unconstitutionally delegate legislative functions to an administrative agency. Id.

The meaning of Bryan is clear to the extent that if Howell v. State, 300 So. 2d 774 (Miss. 1974), see supra notes 174-86 and accompanying text, ever truly expressed the attitude of the states toward delegation of substantive rule making in the area of criminal law, that day is now at an end.

265. See supra note 237 and accompanying text. 
opposed to delegating the "purely legislative authority" of defining crime to administrative agencies, the court is willing to permit delegation of authority to make rules, provided that the rules are within the general policy established by the legislature and adequate safeguards exist to protect against arbitrary administrative action.

It may be that this approach is not substantially different in other states. Possible reasons for the early limitations on state administrative agencies may have been judicial concern with state agencies' lack of professionalism and resources, and the state courts' simultaneous awareness that the often parttime state legislatures were in no position to oversee the operation of state agencies effectively. These conditions have undergone dramatic change, to the point where many state agencies are now as innovative and their staffs as well qualified as their federal counterparts.

In any event, we find that, in at least one state, the state delegation doctrine articulated by Professor Allen simply does not fit. ${ }^{266}$ The question remains whether there is sufficient overlap in the delegation doctrines of the other states to indicate that the model proposed by Professor Allen may also be inappropriate there.

\section{V \\ Due Process and Equal Protection}

The preceding analysis makes it clear that a state statute delegating law enforcement policymaking power to local police would be, at least in one state, a constitutionally permissible delegation of legislative power. This is true even if one concludes that the full enforcement statutes do not grant discretionary authority to the police. ${ }^{267}$ However, since no state legislature has ever explicitly required the formal elaboration of arrest policy, police have not been required to engage in formal policymaking. If the police are not explicitly required to develop such policies, it seems unlikely that they will do so. ${ }^{268}$ A final question, then, is whether additional legal doctrines exist which might encourage or require the police to develop law enforcement policy.

As we have seen, Professor Davis believes that, in spite of the lack of explicit statutory approval, an implicit delegation of such power can be inferred from criminal statutes. ${ }^{269}$ As an initial proposition, he asserts that criminal statutes cannot be fully enforced for at least two reasons: first, the statutes as drafted provide no enforcement guidance; and, second, police agencies are not funded at a level that would make full enforcement possible. According to Davis, state legislators recognize these problems, and not only implicitly authorize selective enforcement rules but expect them. ${ }^{270} \mathrm{He}$ adds

266. Id.

267. Supra notes 48-96 and accompanying text.

268. See G. Williams, supra note 255 , at 19 n.53.

269. See supra note 4 and accompanying text.

270. K. Davis, supra note 1 , at 84-88. 
that rulemaking might be required under the due process clause of the fourteenth amendment primarily on the theory that citizens are entitled to notice of what conduct is proscribed. ${ }^{271}$

Professor Allen does not directly address this argument, but instead sets forth a third reason why the police cannot engage in policymaking-the rejection of the doctrine of desuetude, ${ }^{272}$ which is strongly linked with the due process doctrine. Desuetude provides that failure to enforce a statute over a long period of time, "coupled wih [sic] open and widespread violation" 273 of the statute, results in the equivalent of the repeal of the statute. ${ }^{274}$

It is important to determine the extent to which desuetude has been accepted in America because, according to Professor Allen, law enforcement policymaking would abrogate some criminal statutes. To aid in that investigation, he turns to the work of Professor Arthur Bonfield, who stated that "American courts have come to mouth the view that the vitality of an enacted law can never be impaired by a failure to enforce it. . . . Desuetude is summarily and completely written off as alien to our law . . . ."275 Professor Allen goes on to add that "[I]n the decade since Bonfield wrote, desuetude has fared no better: it was rejected in every case in which it was raised." 276 Professor Allen claims that since law enforcement policymaking would have desuetude-type effect on some criminal statutes, it would be impermissible. ${ }^{277}$

Desuetude questions arise primarily in circumstances in which there is an attempt to enforce a criminal statute which up to that time has been almost totally unenforced. ${ }^{278}$ Such a situation would seem unlikely to arise as a result of implementing police arrest policy where the goal is not to establish a position of total nonenforcement, but rather to attempt to define the circumstances in which every statute will be enforced. This distinction between law enforcement policymaking and desuetude is important and indicates that even if Professor Allen is correct in saying American law does not recognize desuetude, the doctrine of desuetude has limited application to the issue of constitutional validity of criminal law enforcement policymaking.

More important for the analysis of law enforcement policymaking are other points raised by Professor Bonfield in his discussion of desuetude. Bonfield concluded from his research that although desuetude has not been accepted as part of our law, its relationship to American constitutional doctrines of due process, equal protection, and separation of powers makes " $[\mathbf{t}]$ he current notion that in the United States statutes can never be abrogated by the failure to enforce them . . . seem to be an unfounded and overly broad

271. Id. at 138; see supra note 6 and accompanying text.

272. Allen, supra note 2 , at $81-86$.

273. Id. at 81 .

274. Id.

275. Bonfield, The Abrogation of Penal Statutes by Nonenforcement, 49 IowA L. Rev. 389, 429 (1964) (footnote omitted).

276. Allen, supra note 2, at 82 .

277. Id. at 85-86.

278. Bonfield, supra note 275 , at $389-95$ (footnote omitted). 
generality."279 Especially compelling for our present discussion is his analysis of equal protection and due process doctrines. His conclusion that some penal statutes might violate equal protection principles because they permit an administrative authority to wield complete power to define unlawful conduct has direct implications for law enforcement policymaking. ${ }^{280}$ Such absolute power exercised by either an agency or a legislative body could foster the development of irrational and discriminatory enforcement practices.

Professor Bonfield also finds a "notice" problem with desuetude, which is applicable to criminal law enforcement policymaking. ${ }^{281}$ Because general terms in statutes often leave criminal law enforcement decisions solely to law enforcement officers, citizens may not have knowledge of what conduct is practically as well as statutorily proscribed. Consequently, they may be deprived of their due process right to have notice not only of statutory proscriptions but of enforcement practices as well. ${ }^{282}$ To understand fully equal protection and due process problems, it is important to review some of the basic principles of these doctrines.

Law enforcement as an equal protection concern first arose in the case of Yick Wo v. Hopkins. ${ }^{283}$ In Yick Wo, the U.S. Supreme Court struck down a San Francisco city ordinance as violating the equal protection clause of the fourteenth amendment, even though no specific discriminatory intent could be discovered in the language of the statute. According to the Court,

[ $t$ ]hough the law itself be fair on its face and impartial in appearance, yet, if it is applied and administered by public authority, with an evil eye and an unequal hand, so as practically to make unjust and illegal discriminations between persons in similar circumstances, material to their rights, the denial of equal justice is still within the prohibition of the Constitution. ${ }^{284}$

Finding that the enforcing authorities had utilized the ordinance to prohibit Chinese citizens from maintaining lawful businesses, the Court held that the law was unconstitutional. ${ }^{285}$

Yick Wo has come to stand for the proposition that purposeful discriminatory enforcement of a law on the basis of sex, race, or religious or political beliefs is a violation of equal protection. If a person can prove that his arrest was made pursuant to an enforcement policy that deliberately and intentionally discriminated on the basis of any of those criteria, absent a rational basis for such discrimination, the arrest is likely to be found to be in violation of the equal protection doctrine. While this doctrine would, on the surface, seem to provide protection against arbitrary enforcement policy and implicitly call for the development of uniform arrest rules, there appears to be a substantial

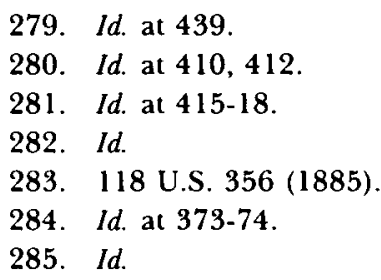


divergence between the theory established in Yick Wo and the reality of treatment by the courts. This seems largely due to the fact that the party who alleges such discrimination must bear an unusually heavy burden of proof on the discrimination issue. ${ }^{286}$

More specifically, acquiring evidence to prove intentionally discriminatory enforcement practices in police work is extremely difficult because a veil of secrecy cloaks law enforcement decisions. ${ }^{287}$. This is a major reason why a substantial proportion of all cases reaching the appellate court level which allege discriminatory law enforcement practices have resulted in the court finding no adequate proof upon which to sustain the accused's allegations. ${ }^{288}$ The legal and practical problems encountered in proving that law enforcement practices are constitutionally invalid are crippling. ${ }^{289}$

286. See infra note 289.

287. For an example of the difficulty of securing documents from police departments, see United States v. O'Neill, 619 F.2d 222 (3d Cir. 1980).

288. LaFave, supra note 69, at 136-37.

289. A typical case is Di Maggio v. Brown, 19 N.Y.2d 283, 225 N.E.2d 871, 279 N.Y.S.2d 161 (1967), in which over one hundred ferryboat officers, appointed to their jobs under a New York State Civil Service law, appealed an administrative decision which penalized them from partaking in a strike in violation of a state law prohibiting strikes by government employees. The officers contended that the enforcement of the law prohibiting civil servants from participating in strikes violated their constitutional guarantee to equal protection because during the preceding 20 years the law had been enforced in only two cases, even though there had been strikes by public employees "too numerous to recall or record." Id. at 289,225 N.E.2d at 874,279 N.Y.S.2d at 165.

The trial court had dismissed the appeal without allowing the officers to prove their claim. Because the trial court had erroneously deprived the officers of the right to offer proof, the appellate court held that the case had to be remitted to trial. More significant to this analysis, the court also held that the officers would face a high standard of proof. Rather than requiring proof of "mere nonenforcement," the court held that

[i]t must be shown that the provisions of [the state law] were enforced against petitioners . . . pursuant to an intentional and invidious plan of discrimination by the Department of Marine and Aviation or by the City of New York. As the Supreme Court stated in Ah Sin v. Wittman, [198 U.S. 500,508 (1905)]: "No latitude of intention should be indulged in a case like this. There should be certainty to every intent."

In addition to the difficulties in proving discriminatory intent with "certainty," a defendant trying to assert an equal protection defense faces significant practical problems. First, the police rarely keep records of policy formulations that might be reviewed to discover discriminatory intent. Furthermore, it is not unknown for law enforcement officials to hamper an accused's attempt to prove that an otherwise valid statute is being enforced in a purposefully discriminatory manner.

United States v. Steele, 461 F.2d 1148 (9th Cir. 1972), is a case in point. In Steele, four persons had been convicted of willful failure to complete their census questionnaires. The four appealed their convictions, alleging purposeful discrimination and contending that the census authorities had singled them out because they had been leaders of a movement urging the public to avoid compliance with census requirements. A regional census official alleged that the four appellants were the only persons known by the agency to have failed to comply with the census regulations. The appellants lacked evidence to prove that the census agency had knowledge of other violators, and the agency refused to supply internal data that might have shown such knowledge. In the end, the appellants did prove, through their own investigation, that at least six other persons had failed to complete their census forms. The appellate court, upon review of the evidence, found that the census authorities should have been apprised of the fact that at least 10 persons had violated the statute. Stating that "an enforcement procedure that focuses upon the vocal offender is inherently suspect," id. at 1052," the court reversed the convictions because "the only plausible explanation on this record is the one urged by Steele." Id.

Finally, as previously noted in Di Maggio $v$. Brown, a claim of discriminatory enforcement may be undermined by the trial court's refusal to admit evidence proffered to show discriminatory enforcement practices. People v. Harris, 182 Cal. App. 2d 837, 5 Cal. Rptr. 852 (1960), a case in which 11 
In summary, an accused person, while theoretically provided a way to challenge police arrest policies as a denial of equal protection of the laws, is met with debilitating legal and practical obstacles. Specifically, the accused must face the problem that police (and prosecutors) rarely keep records of how specific law enforcement decisions are made and, in the rare case in which agency records tend to prove invidious discriminatory intent, these same agencies often effectively deny an accused person's attempts to gain access to such records. ${ }^{290}$ Finally, the courts often erect barriers to the admission of evidence that is the foundation of the claim of constitutionally invalid enforcement. ${ }^{291}$

The existence of law enforcement rules would alleviate many of the present problems of effectuating equal protection principles. Well-drafted rules could provide a general enforcement policy with objective criteria to guide decisionmaking. The call for establishment of standards, although it draws support from and is consistent with equal protection principles, goes

black defendants appealed their convictions under state gambling laws, is a stark example of this evidentiary barrier. In Harris, the petitioners made offers of proof which, if uncontroverted, tended to show that the state gambling laws were clearly being enforced in a discriminatory manner.

Proof was offered to the trial court by the defendants of, among other things, the following:

(1) In 1957, 16 whites and 276 blacks were arrested for gambling.

(2) In 1958, 9 whites and 82 blacks were arrested for gambling.

(3) In 1959, all those arrested for gambling were black.

(4) The police chief was aware of and permitted gambling in three "white" men's clubsincluding one of which he was a member.

(5) According to one police officer it was routine police procedure to patrol the "colored" section of town to find gambling violations, and there was no similar patrol in the "white" section.

Id. at 839,5 Cal. Rptr. at 854 .

The trial court, after reviewing the offers of proof, determined that although "there may be some slight inference [of discrimination], . . . the offer of proof . . f falls short of showing deliberate, intentional, discriminatory practice." Id. at 839, 5 Cal. Rptr. at 853. Accordingly, the trial court rejected the offers of proof and fined each petitioner. The trial court's remarkably high standard for proving an "intentional, discriminatory practice," coupled with its rather summary evidentiary analysis, left the petitioners in a serious economic dilemma: appeal and claim error on the grounds of erroneous rejection of evidence, thus incurring substantial attorney's expenses, or accept the conviction with a negligible monetary sanction. The petitioners chose the former, more financially burdensome, alternative. The appellate court, finding a clear prejudicial error in the rejection of the proffered evidence, reversed the judgment and ordered a new trial. According to the appellate court,

The appellants should have been permitted to introduce any evidence they offered which tended to show actual intentional discrimination in the enforcement of the statute and ordinance in this instance. . . . [W]e are merely holding that [the offered evidence] was admissible in appellants' efforts to prove that defense. It is wholly unsatisfactory to determine whether that defense was sufficient merely on an offer of proof.

Id. at 842, 5 Cal. Rptr. at 855-56.

Recorded rules could also provide a basis upon which an accused person would be able to establish a discriminatory enforcement defense. Such a proposal would not even require shifting the stringent standard of proof to the government; however, upon proof that an officer intentionally violated an enforcement rule, the burden could shift to the state to prove that the arrest was not made with the intent to discriminate against the defendant. What this analysis shows is that an accused person, while theoretically provided a defense to prosecution under intentionally discriminatory enforcement practices, is met with debilitating legal and practical obstacles in asserting the defense.

290. See discussion of United States v. Steele, 461 F.2d 1148 (9th Cir. 1972), supra note 289.

291. See discussion of Di Maggio v. Brown, 19 N.Y.2d 283, 225 N.E.2d 871, 279 N.Y.S.2d 161 (1967), and People v. Harris, 182 Cal. App. 2d 837, 5 Cal. Rptr 852 (1960), supra note 289. 
beyond that doctrine and finds even greater sustenance in due process principles, particularly due process concerns with the "vagueness" of statutes. The Supreme Court's abhorrence of "vague" statutes is well established, and it would seem that vagueness in enforcement policy is at least as serious a problem as vagueness in statutory language. ${ }^{292}$

Professor Davis analogizes statutory vagueness to vagueness of law enforcement policy. ${ }^{293} \mathrm{He}$ finds much to draw upon in the case of Papachristou v. City of Jacksonville, ${ }^{294}$ in which a Jacksonville vagrancy ordinance was held constitutionally void because it "fail[ed] to give a person of ordinary intelligence fair notice that his contemplated conduct [was] forbidden by the statute," 295 and "it encourage[d] arbitrary and erratic arrests and convictions" by leaving unfettered discretion in the hands of the police. ${ }^{296}$

In Papachristou, the Court found that adequate notice had not been provided by the language of the statute, and thus, too much discretion had been left to the police; the statute made criminal a multitude of acts far too broad and diverse to be objectively interpreted. Because of the ambiguity of the statute, the Court felt that neither citizens nor police officers were provided with adequate standards: the vagueness of the statute deprived citizens of appropriate notice of what conduct was unlawful and police officers of necessary standards to determine what actions were proscribed. Statutory vagueness, therefore, created a situation in which the police essentially were left to define criminal acts, resulting in a variable law enforcement policy. ${ }^{297}$

The fact that, because of its vagueness, the statute in Papachristou failed to meet the notice requirement of the due process clause is important in analyzing law enforcement policymaking. As stated by the U.S. Supreme Court in Lanzetta $v$. New Jersey, ${ }^{298}$ "No one may be required at peril of life, liberty or property to speculate as to the meaning of penal statutes. All are entitled to be informed as to what the State commands or forbids."'299 It would seem reasonable, at the very least, that the government be required under the due process doctrine to eliminate barriers to notice caused by unpredictable enforcement practices. Other cases which are set out below support the theory that the principles embodied in the due process clause of the fourteenth amendment imply, if not require, that police agencies act according to uniform standards. Those cases show that the implementation of standards

292. See K. Davis, Administrative Law of the Seventies § 28.00-7, at 629 (1976) (supplement to K. Davis, Administrative. Law Treatise (1958 and Supp. 1970)) (discussing Smith v. Goguen, 415 U.S. 566 (1974)).

293. K. DAvis, supra note 292 , at $626-30$.

294. 405 U.S. 156 (1972).

295. Id. at 162 (citing United States v. Harriss, 347 U.S. 612,617 (1954)).

296. Id. at 162 (citing Thornhill v. Alabama, 310 U.S. 88 (1940))

297. It should be noted that while police rulemaking is constitutional it may not be able to save a statute like the one in Papachristou from constitutional attack.

298. 306 U.S. 451 (1939).

299. Id. at 453 (footnote omitted). In Lanzetta, the Court invalidated a New Jersey statute making it a felony to be a "gangster." The statute defined a "gangster" as "[a]ny person not engaged in any lawful occupation, known to be a member of a gang consisting of two or more persons, who has been convicted at least three times of being a disorderly person . . . ." 
serves to eliminate arbitrary and capricious administrative action, improve the quality of judicial review of administrative decisionmaking, and restore public trust in administrative action.

In Hormsby $v$. Allen, ${ }^{300}$ a case often cited as supporting a "standards" requirement under the fourteenth amendment's due process clause, the plaintiff appealed the decision of the Mayor and Board of Aldermen of Atlanta denying her application for a liquor dealer's license. Plaintiff alleged that the procedure followed by the defendants was arbitrary and capricious and violated due process. Finding that the plaintiff had alleged sufficient facts to show that the administrative procedure did not comport with due process, the Court of Appeals for the Fifth Circuit held that the case had to be remanded to the district court. ${ }^{301}$ The appeals court instructed the district court that, should it find

that no ascertainable standards have been established by the Board of Aldermen by which an applicant can intelligently seek to qualify for a license, then the court must enjoin the denial of licenses under the prevailing system and [sic] until a legal standard is established and procedural due process provided in the liquor store licensing field. ${ }^{302}$

In the Hormsby situation it is evident that effective judicial review of a licensing decision cannot occur unless the agency supplies the reasons for its decision and the facts supporting those reasons. Without judicial review, an arbitrary licensing scheme could easily proceed unchecked. One could argue that Hornsby is not directly applicable to criminal matters as no criminal penalty can be imposed unless evidence supporting the charges against an individual is presented to an impartial tribunal assessing such evidence under a preexisting legal standard. However, as the Supreme Court has determined in the area of the fourth amendment's prohibition against unreasonable search and seizure, if one's due process rights can be effectively denied at the time of arrest, why can they not be violated in deciding to arrest ? $^{303}$ It should be a matter of some concern that we are more interested in the deprivation of economic benefits (as in Hornsby) than in the deprivation of liberty; the latter could be the effect of an arbitrary selection process in criminal cases.

A barrier often confronted by courts reviewing administrative decisions challenged on due process grounds is that there are no "procedures" to review. The lack of "procedures" available for judicial review has led many courts to require agencies to formulate standard-based procedures. ${ }^{304}$ It would be beneficial to the interests of a democratic society to have "procedures" to review in criminal cases as well.

Elimination of covert, arbitrary administrative decisionmaking is one benefit derived from the formulation of standard-based procedures. In Holmes $v$.

300. 326 F.2d 605 (5th Cir. 1964).

301. Id. at 612 .

302. Id.

303. See Amsterdam, Perspectives on the Fourth Amendment, 58 Minn. L. Rev. 349, 434-38 (1974).

304. Infra notes 305-315 and accompanying text. 
New York City Housing Authority, ${ }^{305}$ the Court of Appeals for the Second Circuit expressly sought that "benefit." The plaintiff in Holmes alleged that the Authority annually admitted 10,000 families from a pool of 90,000 applicants to low-rent housing projects without processing the applications "chronologically, or in accordance with ascertainable standards, or in any other reasonable and systematic manner."306 The court stated that there was merit in the plaintiff's claim that the Authority had "failed to establish the fair and orderly procedure for allocating its scarce supply of housing which due process requires." 307 The evil feared by the court was the "intolerable invitation to abuse" 308 created by the existence of uncontrolled discretion by a government agency; "[f]or this reason alone due process requires that selections among applicants be made in accordance with 'ascertainable standards." "309

A second, related benefit derived from the formulation of standard-based procedures is improvement in the quality of judicial review. This interest was significant in the disposition of Environmental Defense Fund, Inc. v. Ruckelshaus. ${ }^{310}$ The Environmental Defense Fund sought judicial review of an order of the Secretary of Agriculture which refused to suspend the federal registration of the pesticide DDT. The Secretary argued that "the suspension of any DDT registration is not warranted at this juncture[,]" 311 without explaining how his decision had been made. The court felt the Secretary had "an obligation to articulate the criteria that he develop[ed] in making each individual decision" 312 and remanded the case to allow for the review of the factors and information which the secretary analyzed in deciding to issue the order. ${ }^{313}$ In support of its holding, the court stated:

[J]udicial review alone can correct only the most egregious abuses. Judicial review must operate to ensure that the administrative process itself will confine and control the exercise of discretion. Courts should require administrative officers to articulate the standards and principles that govern their discretionary decisions in as much detail as possible. ... When administrators provide a framework for principled decisionmaking, the result will be . . . to improve the quality of judicial review in those cases where judicial review is sought. ${ }^{314}$

The public's perception of administrative rulemaking is improved by the implementation of standards. Not only do citizens who have dealings with government agencies have notice of what factors are dispositive; they also are able to participate more fully in governmental decisions. ${ }^{315}$ While the need

305. 398 F.2d 262 (2d Cir. 1968).

306. Id. at 264 .

307. Id. at $\mathbf{2 6 5}$.

308. Id.

309. Id. (citing Hornsby v. Allen, 326 F.2d 605, 612 (5th Cir. 1964)); see Baker-Chaput v. Cammett, 406 F. Supp. 1134,1140 (D.N.H. 1976).

310. 439 F.2d 584 (D.C. Cir. 1971).

311. Id. at 596 n.44.

312. Id. at 596 .

313. Id.

314. Id. at 598 (footnotes omitted).

315. This factor was of importance in Hornby v. Allen, 326 F.2d 605 (5th Cir. 1964); Holmes v. New York City Housing Authority, 398 F.2d 262 (2d Cir. 1968); and Baker-Chaput v. Cammett, 406 F. Supp. 1134, 1140 (D.N.H. 1976). The basic significance of public trust in administrative action 
for standards or rules to control administrative action generally has been recognized, that trend has yet to take hold in the administration of criminal justice. Even if the doctrines of equal protection and due process do not mandate police rulemaking, the principles of fair play and equal treatment embodied in them strongly support the development of law enforcement rules.

On the basis of the preceding analysis, one can make a strong argument that the principles of due process and equal protection include within them support for requiring rules to control law enforcement decisions. ${ }^{316}$ While such rules would not and could not amend criminal statutes passed by state legislatures, they could provide a legal basis upon which agencies might act. Professor Davis sees this as a solution to controlling discretion in the arrest decision. ${ }^{317}$ However, Professor Allen rejects Professor Davis's approach for three reasons: First, as a practical matter, he fears that rules restricting the scope of criminal laws would not be challenged in the courts, because individuals would not be adversely affected. Such rules would therefore have de facto the force of law, which is constitutionally prohibited. Second, he is concerned that the process of labelling the practice of rulemaking as developing interpretative rules in the way Davis suggests does not make the practice any more constitutional than it now is without such a label. Third, the process of labelling avoids resolving the question whether the police have the power to draft such rules in the first place. ${ }^{318}$ The first two concerns are the most important; the third was dealt with in the discussion of equal protection, due process principles, and full enforcement statutes, in which the proposition was developed that equal protection and due process principles ${ }^{319}$ and at least some full enforcement statutes ${ }^{320}$ would appear to support the development of law enforcement policy.

Professor Allen, quite appropriately, is concerned that there is unlikely to be external agency review of police rules. His concern has considerable merit, since at present informal rules are developed and carried out by individual police officers, with virtually no check on the formulation or implementation of those rules by legislative, judicial, or prosecutorial agencies. However, the

was underscored in Baker-Chaput, $406 \mathrm{~F}$. Supp. at 1140. In holding that "the establishment of written, objective, and ascertainable standards is an elementary and intrinsic part of due process," id., the court reasoned that

[t]he absence of standards creates a void in which malice, vindictiveness, intolerance or prejudice can fester. Plaintiff has a paramount interest in receiving those benefits for which she statutorily qualifies. In addition, as a member of our society, she has an interest not only in being treated fairly by the administrative agency, but, just as important, in believing that she has been Id treated fairly. A standardless method of administration negates these interests.

316. See President's Comm'n on Law Enforcement and Administration of Justice, Task Force Report: The Police 94 (1967); Amsterdam, The Supreme Court and the Rights of Suspects in Criminal Cases, 45 N.Y.U. L. REv. 785, 814 (1970); see also Amsterdam, supra note 303, at 416 (police search and seizure activity requires regulation by legal directives confining discretion).

317. K. Davis, supra note 1 , at $112-20$.

318. Allen, supra note 2, at 85-86 n.106.

319. See supra notes $283-315$ and accompanying text.

320. See supra notes $70-96$ and accompanying text. 
implementation of formal rules would contribute to the demise of uncontrolled rule development. Formal rules would require police agencies to be much more careful in developing law enforcement norms. The process of articulating and implementing rules is a significantly more deliberative process than is the application of informal and largely individual norms. Furthermore, for reasons stated below, explicit rules as a practical matter are much more likely to be challenged than is present conduct. While it may be that a person who was not arrested would not challenge such rules, ${ }^{321}$ it seems highly likely that many people who are arrested under such law enforcement rules would question whether such rules violate equal protection and due process guarantees-whether, for example, the rules discriminate against particular individuals or classes of people, or the process of developing and implementing the rules was improper? One could raise questions as Professor Allen does in his article, either about the constitutional power to develop such rules, the procedure by which the rules were developed, or the impact of the rules. ${ }^{322}$ Challenge in the courts, however, is only one way in which such rules are likely to be reviewed. The existence of explicit rules would mean that state legislators, local government officials, prosecutors, and courts could analyze specific enforcement policies and comment on them or, in the case of legislators, promulgate statutes changing them if they so desired. In fact, the existence of such rules would facilitate reform of criminal procedure, because the rules would give the legislatures and courts concrete language to analyze and provide a rare opportunity to evaluate police practices.

The development of such rules under the rubric of managerial instead of legislative rules ${ }^{323}$ might provide a more accurate description of what the police are expected to do. The case law at both the federal and state levels supports the proposition that administrative agencies are expected to have an input into interpreting and implementing their statutory mandate. Skidmore $v$.

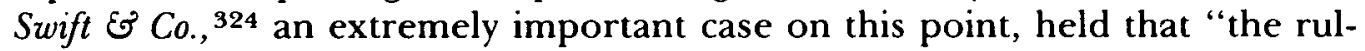
ings, interpretations, and opinions of the Administrator under [the Fair Labor Standards Act], while not controlling upon the courts by reason of their authority, do constitute a body of experience and informed judgment to which courts and litigants may properly resort for guidance." 325

Cases at both the federal and state levels have reaffirmed the principle of Skidmore. For example, the Iowa case of Holland $v$. State, ${ }^{326}$ while holding that a particular rule violated statutory authorization, clearly established that state

321. Allen, supra note 2 , at 85-86 n.106.

322. Id. at 104-05.

323. See K. Davis, supra note 1 , at 110.

324. 323 U.S. 134 (1944).

325. Id. at 140. This position has been reaffirmed in Morton v. Ruiz, 415 U.S. 199 (1974), which held that " $[t]$ he power of an administrative agency to administer a congressionally created and funded program necessarily requires the formulation of policy and the making of rules to fill any gap left, implicitly or explicitly, by Congress." Id. at 231.

326. 253 Iowa 1006,115 N.W.2d 161 (1962). 
agencies could promulgate appropriate rules. ${ }^{327}$ More closely analogous to the present concern is the action of the Iowa Supreme Court in Wagner $v$. Northeast Farm Service Co ${ }^{328}$ In that case, the court indicated that policy guidelines which "fill in an implicit gap" in statutes by providing discretionary standards would be appropriate because only in such a way would it be possible to ensure the effective realization of the legislature's policies. ${ }^{329}$

At least one other case can be cited in support of the proposition that agencies are required to develop rules to guide both their substantive and procedural activities. In Citizens Against the Lewis E' Clark (Mowery) Landfill v. Pottawattamie County Board of Adjustment, ${ }^{330}$ specific administrative action was invalidated because the court found that the administrative body failed to adopt rules as directed by both state statute and local ordinance. ${ }^{331}$ There is important language in the case which says that "the weight of authority is to . . . condemn the failure to adopt procedural rules, whether demanded by statute or not." 332 The court cited a number of cases dealing with mixed substantive and procedural problems to show "the necessity for some rules to govern the conduct of proceedings" before agencies. ${ }^{333}$ The court went further and stated that although there was no statutory requirement for the agency to make written findings, such findings "would be of great benefit . . . to the trial court . . . . They would provide a ready basis for determining the reasons for the board's action and would help immeasurably in determining whether the result was reasonable or was, as is frequently claimed, arbitrary and capricious." 334

The court felt that the need for written findings was so important that it stipulated in the holding of the case that all similar agencies were to make written findings of fact after the date the opinion was filed. ${ }^{335}$ The same idea was expressed in Sun Ray Drive-In Dairy, Inc. v. Oregon Liquor Control Commission. ${ }^{336}$ The Court of Appeals of Oregon stated:

\footnotetext{
An administrative agency cannot properly perform its duty under the law unless employees at all levels work toward the same objectives under a clear direction of policy from the head of that agency. . . . The public is entitled to consistency of enforcement from the agency. That situation cannot be achieved in the absence of written standards. ${ }^{337}$
}

The principle established in Sun Ray, that agencies promulgate standards to guard against the arbitrary exercise of administrative power, applies to the police as well. When arrest powers are exercised without rules, they can violate due process.

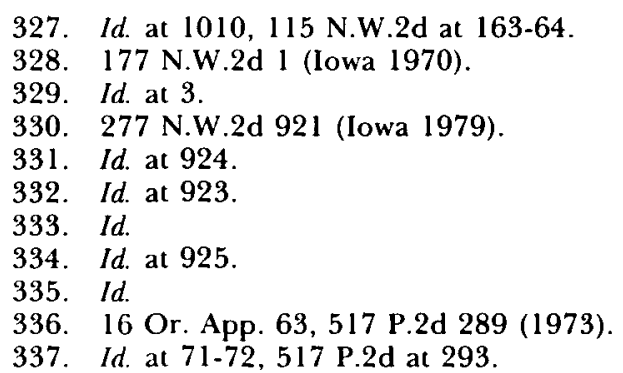


Support at the state level for the idea that development of rules to control law enforcement policy is contemplated by state legislatures may be found in many state administrative procedures acts. ${ }^{338}$ For example, Iowa's Administrative Procedure $\mathrm{Act}^{339}$ can be interpreted as suggesting that state police agencies develop rules to control arrest policy. ${ }^{340}$ The Act not only gives state administrative agencies the power to make rules "of general applicability that implement[,] interpret[,] or prescribe[,] law or policy,"'341 but seems to indicate that while agencies may not be required to divulge such rules, they are expected to make them. ${ }^{342}$ Allen states that it is unclear whether the police are included in the Act.

Although the Act authorizes a state agency to establish law enforcement policy, the Act does not explicitly include within its purview local police departments; yet, a persuasive argument can be made that local police departments are "quasi-state administrative agencies" and thus included under the Act owing to the fact that they derive their power and authority from the state, ${ }^{343}$ implement the will of the state legislature, ${ }^{344}$ and are selected ${ }^{345}$ and trained $^{\mathbf{3 4 6}}$ according to state mandates. This line of thinking is consistent with the approach of one state supreme court. ${ }^{347}$

In fact, the inclusion of some, but not all, law enforcement officers who are responsible for enforcing state criminal laws within the purview of a state administrative procedure act is more than a little ironic. Most citizens are likely to have more contact with municipal police than with any state law enforcement agency; yet, a uniform approach with regard to arrests is expected at the state, but not the local level. This is clearly an intolerable anomaly which cries out for rectification.

\section{VI}

\section{Conclusion}

This survey of the constitutional and legal impediments to the development of law enforcement rules shows that the police do have authority to

338. E.g., IOWA CODE §§ 17A.1-17A.23 (1981).

339. Id.

340. See IOWA CoDE § § 17A.2-7 (1981).

341. IOWA CODE $\S 17$ A.2(7)(1981).

342. Id.

343. Hagedorn v. Schrum, 226 Iowa 128, 283 N.W. 876 (1939). "The law of Iowa is well settled that a law-enforcing officer, whose office is created by the statute of the State and whose duties are prescribed by statute, is an agent of the public in general and is not the agent of the municipality, even though he is chosen by the municipality and is paid by it." Id. at 130, 283 N.W. at 877 (emphasis added); see also IOWA CODE $\S \S 364.1,372.4,372.5,372.14$ (1981).

344. IOWA CODE $\$ 80 \mathrm{~B} .2(1981)$.

345. IOWA CODE $\$ 80 \mathrm{~B} .11(4)(1981)$

346. IOWA CODE $\$ 80 \mathrm{~B} .1$ 1 (2) (1981). For a listing of those states in which the local police were considered state officers, see Ex parte Corliss, 16 N.D. 470, 500, 114 N.W. 962, 975 (1907).

347. Maquoketa Valley Community School Dist. v. Maquoketa Valley Educ. Ass'n, 279 N.W.2d 510 (lowa 1979). Also, the case of Hagedorn v. Schrum, 226 Iowa 128, 130, 283 N.W. 876, 877 (1939), makes it clear that local police in lowa are state officers. While that opinion was modified to some extent by Strong v. Town of Lansing, 179 N.W.2d 365 (Iowa 1970), Hagedorn was not overruled. 
develop rules to control arrest decisions and that police agencies should embrace and use that authority to provide greater uniformity in decisionmaking. Courts should likewise recognize police rulemaking.

One need only look to the institutional evolution of the police to support this conclusion. American police have always been expected to exercise discretion in the performance of their duties. This is not to imply that there has been no concern with how that discretion is exercised; rather, the concern appears to have been that partisan politics not affect the exercise of discretion. The fear of politics intruding into law enforcement decisions was likely to have been one of the factors influencing passage of the "full enforcement" statutes. Reviewing those statutes in their historical context leads one to the conclusion that they were directed not so much against police decisionmaking as toward the problems of controlling political influence and providing structure for governmental institutions. While the statutes may have had some impact on limiting the political influence on police action, they never totally controlled the arrest decisions of the officer on the street; nor, as a practical matter, were they intended to do so. Discretion under those statutes was and is expected.

A review of state constitutional separation of powers and delegation principles likewise leads one to conclude that the police have the power to develop law enforcement rules. Analysis of those principles supports the proposition that the police may, at the very least, develop arrest guidelines to control police discretion in minor or low visibility crimes. Such matters are analogous to those regulated in the normal course of the work of administrative agencies.

Finally, if the police do not have explicit uniform arrest guidelines, it is clearly within the scope of the courts' authority to interpret the constitutional doctrines of due process and equal protection as requiring them.

\section{VII}

EPILogue

Professor Allen was very kind in his comments about this article and I cannot begin to repay my debts to him for his willingness to discuss this issue with me and to encourage me to continue my quest for the key to the troubling questions surrounding police discretion, even when the search might lead me to disagree with him. But I do have to disagree.

The difficulty is that police discretion issues are for the most part sub rosa. They exist in the public eye at almost a subliminal level. My concern is that such discretion be recognized and exercised within clear guidelines. ${ }^{348}$ Explicit examples of police discretion are found infrequently. The problems exist in most communities, however. For example, a rare public glimpse of

348. Williams, supra note 10. 
the problem was provided recently in Iowa. An Iowa community was considering a zoning ordinance that would make it illegal for unmarried or unrelated persons to live together. In response to the argument that the ordinance would be discriminatory, city council members made it clear that they did not expect that the law would be fully enforced but that it "would be enforced only when neighbors complain about large gangs of unrelated people sharing a house in single-family and two-family zones." 349 Thus, under the ordinance, law enforcement officials would be expected to exercise discretion not to enforce the law in specific situations. The above is a clear and uncharacteristically candid charge from a legislative body to its law enforcement agency.

Aside from practical concerns, perhaps the more important question on the validity of such exercises of discretion is how judicial bodies interpret statutes and ordinances where such an explicit legislative history does not exist. Gowan v. Smith, ${ }^{350}$ in spite of Professor Allen's comments to the contrary, ${ }^{351}$ is clearly a case which explicitly recognized the need for discretionary decisionmaking by police officers.

The validity of discretionary enforcement comes even more directly to the surface in other more recent cases. In the very recent case of Hildenbrand $v$. Cox, ${ }^{352}$ for example, the Iowa Supreme Court, while explicitly addressing the question of whether the granting of summary judgment was proper, addressed substantive questions of police discretion in the enforcement of the criminal law.

Hildenbrand v. Cox involved a woman's suit against a Corydon, Iowa, police officer and the city of Corydon for the negligent failure of the officer to arrest her intoxicated husband or place him in protective custody. The police officer investigated an accident during which the husband drove into a flower pot in the town square of Corydon. The police officer suspected that the husband was intoxicated and conducted a field sobriety test. The officer decided not to arrest Mr. Hildenbrand for intoxication, but rather to issue a citation for failure to control his vehicle. Shortly after the incident, Mr. Hildenbrand was killed in another accident.

In addressing the substantive claim made by Mrs. Hildenbrand, the court found no common law duty to discover the deceased's intoxicated condition and arrest him. The court established the general proposition that "police officers necessarily exercise broad discretion in investigating accidents and determining the manner in which they will enforce laws." 353 But the court did much more than cite general propositions. Justice Wolle turned to specific state statutes to assess whether there might have been a breach of statutory duty in the case. Justice Wolle examined a number of statutory provisions

349. Des Moines Register, June 27, 1985, at 1A, col. 3.

350. 157 Mich. 443, 122 N.W. 286 (1909).

351. Allen, Foreword, The Nature of Discretion, Law \& Contemp. Probs., Autumn 1984, at 8-9.

352. No. 103/84-1031, slip. op. (Iowa June 19, 1985).

353. Id. at 8 . 
which generally proscribe arrest powers, ${ }^{354}$ define the crime of drunk driving, ${ }^{355}$ and define public intoxication. ${ }^{356}$ Justice Wolle concluded from his review of the statutory provisions that they did not impose any absolute duty to detect Hildenbrand's intoxicated condition and take him into custody.

We believe that the legislature intended by these provisions to give peace officers several options which include both the authority to arrest persons violating laws governing intoxication and the authority to take such persons to treatment facilities. The statutes do not impose on peace officers a mandatory duty to take such persons into custody. ${ }^{357}$

The Iowa Supreme Court, in deciding to uphold the decision of the officer not to make a custodial arrest, has explicitly recognized that the legislature has the power to delegate decisionmaking authority to the police. Thus, Hildenbrand represents another and more recent decision supporting the thesis of this article.

A second case decided since the preparation of this article goes even further than the Hildenbrand decision and not only fails to find an affirmative statutory duty to arrest in facts similar to Hildenbrand, but specifically rejects any suggestion that a so-called "full enforcement" statute imposes any mandatory duty of arrest. In Everton v. Willard, ${ }^{358}$ a Florida court "reject[ed] any assertion" 359 that the Florida full enforcement statute created "a special standard of duty and liability for sheriffs and their deputies." 360 In looking at these decisions, one must conclude that the central issue of police discretion questions in the future will not be whether the police have the authority to exercise discretion in the enforcment of the criminal law, but how that discretion might best be structured and controlled. ${ }^{361}$

354. IOWA CODE $\$ 804.7$ (1983).

355. Id. $\$ 321.28(1983)$.

356. Id. § 123.46 (1983).

357. Hildenbrand v. Cox, No. 103/84-1031, slip. op. at 13 (Iowa June 19, 1985).

358. 426 So. 2d 996 (Fla. App. 1983), affd, 468 So. 2d 936 (Fla. 1985). For a similar approach on the conclusion of no public duty to arrest an intoxicated person, see Shore v. Stonington, 444 A.2d 1379 (Conn. 1982); for a contrary approach on the public duty to arrest intoxicated persons, see Huhn v. Dixie Ins. Co., 453 So. 2d 70 (Fla. App. 1984), quashed, 468 So. 2d 963 (Fla. 1985).

359. 426' So. $2 d$ at 1004 .

360. Id.

361. Williams, supra note 10. 


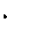

